\title{
Petrophysical Signatures and Water-Reservoir Potential of Southern Apennines Turbiditic Sandstones Suites
}

\author{
Borrelli $\mathrm{M}^{1}$, Criniti $\mathrm{S}^{1}$, Critelli $\mathrm{S}^{1 *}$, Di Nocera $\mathrm{S}^{2}$ and Matano $\mathrm{F}^{3}$ \\ ${ }^{1}$ Dipartimento di Biologia, Ecologia e Scienze della Terra, Università della Calabria, Rende (CS), \\ Italy \\ ${ }^{2}$ Univeristà Federico II, Naples, Italy \\ ${ }^{3}$ CNR-ISMAR, Naples, Italy
}

Research Article

Volume 4 Issue 3

Received Date: June 22, 2020

Published Date: June 30, 2020

DOI: $10.23880 /$ ppej-16000228

*Corresponding author: Salvatore Critelli, Dipartimento di Biologia, Ecologia e Scienze della Terra, 87036 Rende (CS), Italy; Tel. +390984493678; Email: salvatore.critelli@unical.it

\section{Abstract}

After the seismic event of Irpinia (Southern Apennines), occurred on November 23rd 1980, the Pavoncelli tunnel, that used to supply with water the Puglia Region, was seriously damaged. Because of the strategic importance of this civil engineering work, a new water tunnel named Pavoncelli-bis that should substitute the previous one, was built and finally tested during the end of the 2019. The geological features of the area, highlighted the presence of three main siliciclastic formations (Corleto, pre-Numidian/Numidian and Castelvetere formations), crossed by the tunnel trace, that were petrophysically analyzed through the mercury injection porosimetry for a better definition of their petrophysical signatures and related water-reservoir potential at regional scale as hydrocarbon-reservoir potential. Data highlighted the presence of two clusters: one represented by the Corleto and Pre-Numidian Fms. showing good permeability (respectively $181.70 \mathrm{mD}$ and $122.25 \mathrm{mD}$ in median) and low porosity (respectively $4.56 \%$ and $3.94 \%$ in median); the other, represented by the Castelvetere Fm. highlighting good porosity ( $9.58 \%$ in median) and a very low permeability (4.84 $\mathrm{mD}$ in median). Permeability, more than porosity, affects the cluster differentiation, whereas the other variables (average pore diameter and nanopores volume) do not show any particular trend. All these petrophysical parameters were compared with the sandstone composition (Qm, F, Lt), highlighting that porosity results negatively correlated to monocrystalline quartz $(\mathrm{Qm})$ and positively correlated with feldspars $(\mathrm{F})$. The lithic fragments values (Lt) are sparse and do not show any specific trend. The variability of porosity is directly linked with the diagenetic processes that interested the clusters of the Corleto and pre-Numidian Fms. (rich of Qm) and the Castelvetere Fm. (rich of F). Particularly, where quartz is more abundant, quartz cementation and overgrowth are more efficient and widespread, resulting in a reduction of the porosity. On the contrary, where feldspars are abundant, during diagenesis their dissolution can create new pore spaces and also clay-minerals with a better porosity than the previous feldspars. Moreover, clay-minerals can coat the quartz grains present in the sandstones inhibit the porosity loss of the quartz cementation and overgrowth. However, despite an increase in porosity, permeability decreases because the authigenic clays is mainly formed by isolated and blind pores.

Keywords: Porosity; Permeability; Sandstone composition; Turbidite Sandstone Reservoirs; Southern Apennines, Italy 


\section{Petroleum \& Petrochemical Engineering Journal}

\section{Introduction}

The Southern Apennines can be designed as a NW/ SE oriented arcuate belt, mostly derived from the Neogene E-verging thrusting and folding of a Mesozoic passive margin and the related oceanic sediments that were imbricated, with duplex structures, and also broke-up by extensional tectonics [1-4]. The complex geodynamic configuration of this area (and specifically Irpinia and Lucania zones-Figure 1), results in the occurrence of numerous seismic events, also characterized by a great magnitude, that brought it to be considered as one of the riskiest zones for seismic hazard of all the Italian peninsula (together with Calabria). This was proved by the occurrence of strong earthquake events during the last centuries that culminated on November 23rd 1980 with the Irpinia-Lucania earthquake (MS 6.9 - Imax X MCS), that still represents the most devastating seismic shock occurred in Italy in the XX century in terms of loss of human life and destruction of cultural heritage. The earthquake, moreover, caused also relevant hydrogeological changes to several springs and severe structural damages to major strategic civil engineering works throughout the Irpinia sector. One of the works that was most affected by the ' 80 seismic event was the Pavoncelli hydraulic tunnel located between the Caposele spring of the Sele river and the Conza della Campania dam, located along the Ofanto river (Figure 2). The Pavoncelli water supply tunnel, built in 1911 [5], was located just in the epicentral area of the 1980 earthquake and consequently suffered relevant damages mainly consisting in crushing of sidewalls and roof and in vertical to transversal ruptures of the design section [6]. The high level of occurred damages, despite the undeniable entity of the seismic event, could also be linked with the ineffectiveness of the technical rules in force at that time for engineering works and to the poor geological knowledge of the stricken territory regarding to several aspects (seismology, stratigraphy, tectonics and geomorphology) $[7,8]$. Because of the strategic relevance of the hydraulic tunnel, in recent years new data have been collected with the aim to build a new tunnel, named Pavoncellibis, that could replace the older one. The subsurface excavation of the tunnel (then completed and tested during the 2019) permitted to greatly constrain the stratigraphic setting and the geological structures of the area, where the tectonic events of the Apennine chain almost completely hidden the original geometric relationships of the various geological units [9]. Particularly, a new detailed geological model was provided and, for the first time, the presence of quartzolithic arenaceous successions with volcanoclastic composition, related to the Early Miocene arenaceous successions Corleto/Albanella Sandstone Formations, and a quartz-feldspathic arenaceous successions, related to the late Miocene Castelvetere Formation, have been documented in an exhaustive way [9] (Figure 3). These arenitic sequences, together with the Pre-Numidian sandstones, represent the main formations intercepted by the tunnel (Figures $4 \& 5$ ). Consequently, though a focus on the detrital mode definition and on their relationship with petrophysical parameters such as porosity, permeability and nanopores volumes [10-14], this paper provides new petrophysical data useful to define the water-reservoir potential of these arenitic sequences, and consequently, optimize the exploitation of the management of the water reserves of the Pavoncelli-bis tunnel.

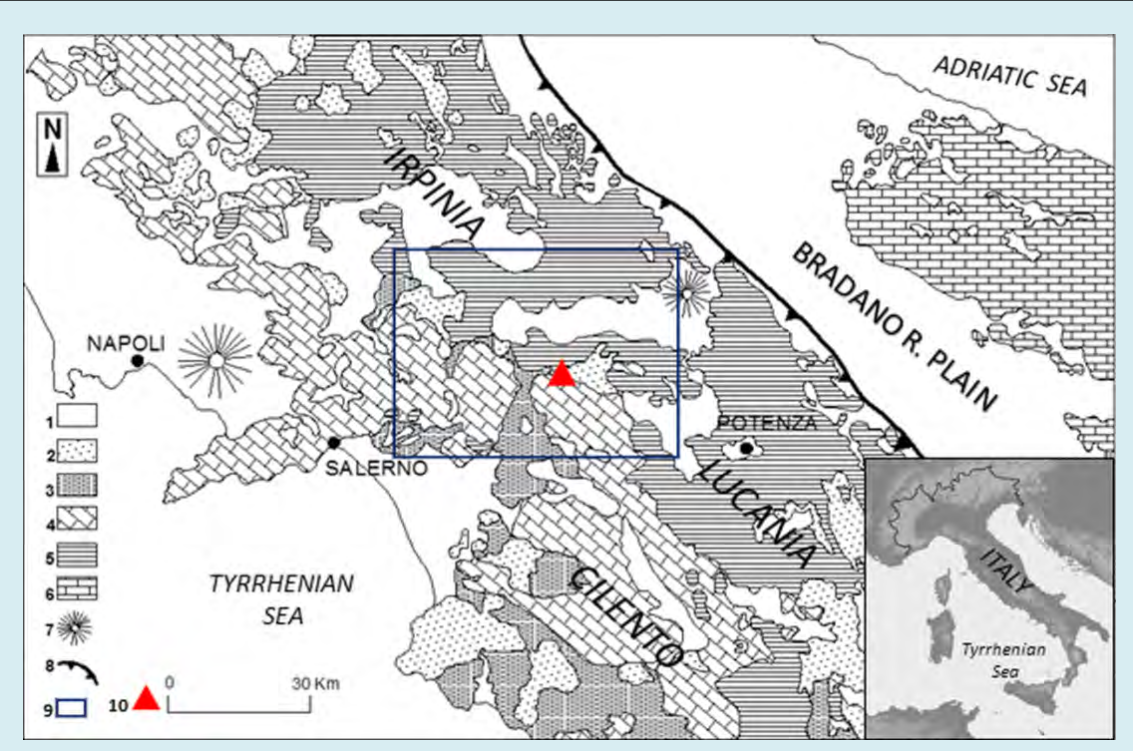

Figure 1: Geological sketch-map of the Southern Apennines and study area location (inlet). Legend: 1. Quaternary and Pliocene deposits; 2. Miocene deposits; 3. Liguride Complex; 4. Apennine carbonate platform units; 5. Molise-Lagonegro basin units; 6. Apulian carbonate platform units; 7. Volcanoes; 8. orogenic front; 9. study area of Figure 2.; 10. 1980 earthquake epicenter. 


\section{Petroleum \& Petrochemical Engineering Journal}

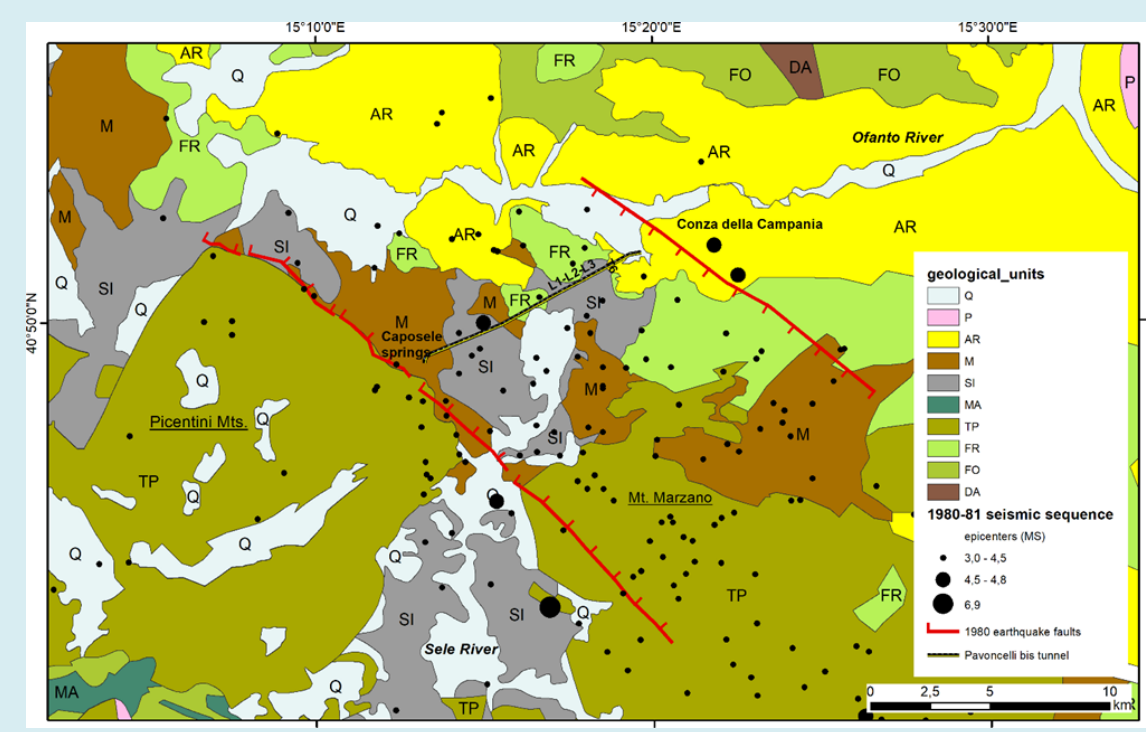

Figure 2: Geological map of the study area and seismic effects epicenters of 1980 earthquake seismic sequence. Legend: $Q$, Quaternary deposits; P, pyroclastic and volcanic deposits; AR, Ariano unit (Pliocene); AL, Altavilla unit (Late Miocene); M, flysch units (Middle-Late Miocene); SI, Sicilide and Liguride units; MA, Monte Croce unit; TP, Apennine carbonate platform units; FR, Frigento unit (Lagonegro basin); FO, Fortore unit (Lagonegro basin); DA, Daunia unit.; earthquake faults [15-16].

\section{Geological and Stratigraphic Setting}

\section{The Southern Apennine Context}

The Southern Apennine foreland region (Figures 1 \& 2) preserves clastic wedges with contrasting and mixed sandstone petrofacies in which the key provenance terranes are coming from the Alps, at its northern edge; from the Sardinia-Corsica block, at its western edge; and from the eastern margin of the Mesomediterranean microplate (mainly the Calabrian terranes) at its western and southern edges. Additional provenances of foreland sandstones are from the progressively deformed Adria continental margin, and the active volcanism in the central Mediterranean region since the late Oligocene [17-26]. Since the early Miocene, the Apennine domain represents the place where huge volume of dominantly deep-marine turbiditic strata deposited in response of E-NE accretionary processes along the Adria plate [27-29]. The foreland basin system (i.e. wedge-top, foredeep, forebulge, back-bulge depozones) migrated in time and space, and siliciclastic and carbonatoclastic deposits, filling the wedge-top and the foredeep, derived from progressive unroofing of crustal blocks of Alps, Sardinia-Corsica and Mesomediterranean microplate or from erosion of the Adria forebulge [17-18,24,26,29-31]. Final closure of the eastern Tethyan ocean realm (Lucanian ocean basin) and the onset of continental accretion in the southern Apennines are dated as early Miocene (late Burdigalian). The provenance of the detrital constituents of the Miocene foreland sandstones was dominantly from the eastern continental margin of the Mesomediterranean microplate (Calabrian terranes), the obducted Tethyan ophiolitic units, and the deformed and thrusted western margin of the Adria plate, representing the active growing front of the fold-thrust belt [17-18,20-22,26] (Figure 1). Additional detrital signatures come also from active Cenozoic volcanism of the central Mediterranean [18]. Finally, during the last $10 \mathrm{My}$, named as Tyrrhenian phase (15-0 Ma) several processes occurred, such as: the fragmentation and dispersion of pieces of the Mesomediterranean plate (Calabria, Sardinia, Corsica); the increasing in the displacement of the accretionary prism over the Adria plate; the eastward migration of the magmatic arcs; and the roll-back of the Adriatic lithosphere [32-38]. This led to eastward migration (northeastwards in the northern Apennines and southeastwards in Calabria and Sicily) of the Tyrrhenian back-arc basin at velocities of up to $5-7 \mathrm{~cm} / \mathrm{y}$ in the most arcuate parts of the arc [26,38-39].

\section{Geological and Stratigraphic Setting of the Study Area}

The study area, located between the Sele and Ofanto rivers (Southern Apennines) (Figure 2), was deeply analyzed through a detailed geological survey by Matano, et al. [9], who defined the presence of four main regional tectonic units (Figure 3), referred to different palaeogeographic domains, such as the Sicilide unit (Lucanian basin), the Mt. Picentini and Mt. Marzano units (Apennine platform) and the Frigento unit (Lagonegro basin).

The Sicilide Unit, Cretaceous to Oligocene-Early Miocene in age, is composed by calcareous-pelitic deposits 


\section{Petroleum \& Petrochemical Engineering Journal}

forming the Argille Varicolori Superiori (ALV) and the Monte Sant'Arcangelo Fm. (FMS), both belonging to the Argille Variegate Group (AV) [40] (Figure 3) that are in turn overlain by siliciclastic, volcaniclastic and calciclastic strata of the Corleto Arenite and Albanella Arenite (ABA) formations. The Monte S. Arcangelo Fm. (FMS), Eocene-Upper Oligocene [40] in age, can reach a thickness of about $350-400 \mathrm{~m}$. It is characterized by marly limestones sometimes silicified, and subordinately, by graded and laminated calcarenites, dark clayey marls, thin bedded silty marls and micaceous arenites layers. The Argille Varicolori Superiori Fm. (ALV) that stratigraphically overlies the FMS, is Oligocene - Aquitanian [40] in age and reaches a thickness that does not exceed $250 \mathrm{~m}$. It is generally composed by clays with thin layered limestones and marly limestones, related to a deep marine basin depositional environment. Some horizons, up to $100 \mathrm{~m}$ thick, are made of thick bedded limestones, marly limestones and marls, whitish-greyish calcarenites and calcareousmarly turbidites characterizing a calcareous lithofacies $(A L V c)$. This unit (ALV) passes laterally and vertically into the Lower Miocene Albanella/Corleto unit (ABA). This latter, characterized by a thickness of $50-100 \mathrm{~m}$, is formed by thin bedded brownish quartz-micaceous sandstones with planar and convolute laminations, poorly cemented yellowish and grey clayey marls, siltstones, blackish shales with calcite veins.

The Mt. Picentini and Mt. Marzano units, are characterized by carbonate successions ranging in age between Noric and Late Maastrichtian, and represent different margin sectors of the carbonate platforms facing the Lagonegro basin.

The Mt. Picentini unit is Triassic to Lower Cretaceous in age and in its lower portion includes the Dolomia Superiore fm. (DBS), with a total thickness exceeding 1000 $\mathrm{m}$. This latter is characterized by laminated stromatolites, alternated with massive dolostones rich in megalodontids levels (DBS4) representing a peritidal environment. The limestone and dolomitic limestone fm. (CLU) follow in the succession. It reaches a thickness of $400 \mathrm{~m}$ and is composed by oncolitic light grey limestones, calcarenites, light brown calcilutites with rare thin shells of small sized gasteropods. The CLU vertically and laterally grades into a first oolitic/ oncolitic limestone fm. (CDO) in turn passing upward into the Cladocoropsis and Clypeina limestone fm. (CCM). This latter, is characterized by lagoonal facies represented by mudstones, wackestones and packstones interbedded with thin bedded marls and in the upper part by limestones with dasycladacean algae. The thickness is at least $450 \mathrm{~m}$. Then the requienia and gasteropods limestone fm. (CRQ) follows in the succession. It reaches a thickness of about $450 \mathrm{~m}$ and is composed by limestones rich in nerineids and requienia, occasionally giving rise to bioclastic rudstones, alternated with mudstones and wackestones. Limestones with oolites, limestones with alveolinids and laminated dolostones are also present. Upward the Radiolitidae Limestone $\mathrm{fm}$. (RDT) occurs. It is formed by thick to medium strata of gray and white dolomitic limestone and clastic limestone rich in rudists. The thickness is about $300 \mathrm{~m}$. The biolitoclastic rudists limestone $\mathrm{fm}$. (CBI), in some parts lateral to the RTD, is formed by massive bioclastic carbonates (rudstones and floatstones) with abundant large fragments of rudists and large gastropods and with thin beds of yellowgreenish marly limestones. A lithofacies with thick bedded "pseudosaccharoidal" carbonates and graded calcarenites is present. These facies testify an open carbonatic ramp grading into an upper slope environment. The age is Upper Cenomanian - Paleocene, the thickness is about $300 \mathrm{~m}$.

The Mt. Marzano unit crops out along the norther slope of Mt. Marzano massif and consists, in the lower part, of the DBS, CLU, CRQ and CPL units; whereas in the upper part, a discontinuous succession, Upper Cretaceous - Lower-Middle Miocene in age, is composed of the typical "pseudosaccharoidal limestones" units (CBI). The Laviano calcareous-pelitic sequence (LIA) and the Mt. Sierio calciclastic Fm. (SIE) occur upward. Since all the lower units and part of the upper units are analogous to the formations already characterized for the Mt. Picentini unit, the description starts from the Laviano calcarenites fm. This latter, Serravallian - Lower Tortonian in age [40], reaches a thickness of about $100 \mathrm{~m}$ and overlies in paraconformity the CBI. It is formed by a sequence comprising medium to thin layered laminated calcarenites and marly limestones, alternated with marls and silty shales. The strata are formed by turbidites related to basin-slope environment, and hemipelagic deposits. The succession is finally unconformably overlaid by the Monte Sierio Fm. (SIE), formed by calcirudites and calcarenites rich in Nummulites and alveolines bioclasts; locally marly calcilutites, laminated and silicized siltstones, laminated lithic sandstones, calcarenites with nummulites and orbitoids, blocks and strata composed of "numidian" sandstones are present. The thickness is not less than $150 \mathrm{~m}$ and the age is Upper Tortonian.

The Frigento Unit consists mainly of Cretaceous to Early Miocene basinal and shelf-margin facies successions, characterized by calcareous clastic and pelitic turbidite associations laterally and vertically passing to marlycalcareous successions; a debris calcareous clastic lithofacies is present at different heights. The succession starts with the Flysch Galestrino fm. (FYG), Upper Jurassic p.p. - Cretaceous in age, that is formed by siliciferous marls and clays with intercalations of silicified calcarenites and calcilutites; dark grey siliceous shales with intercalations of grey calcilutite in layers up to $30 \mathrm{~cm}$ thick are also present. The unit crops out discontinuously with thicknesses around few tens of meters and represents a bathyal environment with both siliciclastic 


\section{Petroleum \& Petrochemical Engineering Journal}

and carbonatic turbiditic inputs. Then the Flysch Rosso Fm. (FYR) follows in the succession. It is characterized by different members spanning from Cretaceous to Early Miocene and reaches a total thickness of about $500 \mathrm{~m}$. It is generally formed by marls and clays, thin bedded calcilutites, medium bedded commonly graded and laminated calcarenites with Alveolinidae, Nummulites and Orbitoides, thick bedded lithoclastic calcirudites with rudist fragments. The limestone member (FYR2) is formed by grayish and white clastic limestone (calcirudites, crystalline limestone, breccias, calcarenites) in thick and very thick massive layers, with irregular stratification, resting with erosive contact on grayish clayey-marly horizons cleavage fractures. In the upper part of the formation a "pre-numidian sequence" occurs showing the gradual transition to Numidian Flysch (FYN). It is formed by grey-green silty clays with intercalations of medium to thick bedded yellowish calcarenites rich in quartz granules. The Flysch Rosso Fm. passes gradually upward to the upper Burdigalian - upper Langhian p.p. Numidian Flysch (FYN) characterized by very mature sandstones (quartzarenites) with alternations of calcarenites and marls.

The turbiditic, grain-flow and hemipelagic siliciclastic deposits of the Castelvetere Formation (CVT) and the clastic Pliocene units (SAD and RVM) present an unconformable lower boundary overlying almost all the deformed Sicilide, Mt. Picentini, Mt. Marzano and Frigento units. The Castelvetere Fm. (CVT), Upper Tortonian - Lower Messinian in age, shows a thickness of about $250 \mathrm{~m}$. The lower part is formed by arenites and granular conglomerates in thick beds with lens-shaped geometry and erosive base, locally amalgamated, containing thin pelitic interlayers, locally reddish and rich in coal fragments, and by quartz-feldspathic arenaceous turbidites and paraconglomerates. The upper part is characterized by silty-clayey-marly lithofacies (CVTa) formed by yellowish quartz-micaceous arenaceous siltstones in thin beds with planar and convolute laminations within clays and grey-green silty marls, reaching a thickness of about $150 \mathrm{~m}$. The basal coarse sequences represent channeled facies rich in detrital deposits (olistolites) and clayey landslides (olistostromes) that are present at different stratigraphic levels. The upper finer sequence is linked to a turbidite system formed by depositional lobes and overbank deposits.

The Pliocene units are two, the Andretta Synthem (SAD) and the Ruvo del Monte Synthem (RVM). The Andretta Synthem (SAD) is formed by continental fan-delta conglomeratic and sandy deposits passing to coastal marine sands and clays. The thickness is of about $150 \mathrm{~m}$, and the age is referred to the Early Pliocene (biozone MPl3/MPl4a). The Ruvo del Monte Synthem (RVM) is about $200 \mathrm{~m}$ thick and EarlyMiddle Pliocene in age (biozone MPI4a); it consists mainly of arenitic-sandy-conglomeratic deposits from paralic to continental environment.

Among the Quaternary units, the Conza della Campania synthem (CZC) crops out with terraced fluvial deposits along the Ofanto river and around the Conza lake. Usually the succession is formed by gravel lens, pale yellow sands, silts, and gray to brown clayey silts, and is $10 \mathrm{~m}$ thick. The age is referred to Middle Pleistocene - Holocene. More recent deposits linked to the active geomorphic processes are mainly represented by debris slope talus, terraced and actual alluvial deposits and alluvial fan and landslide deposits.

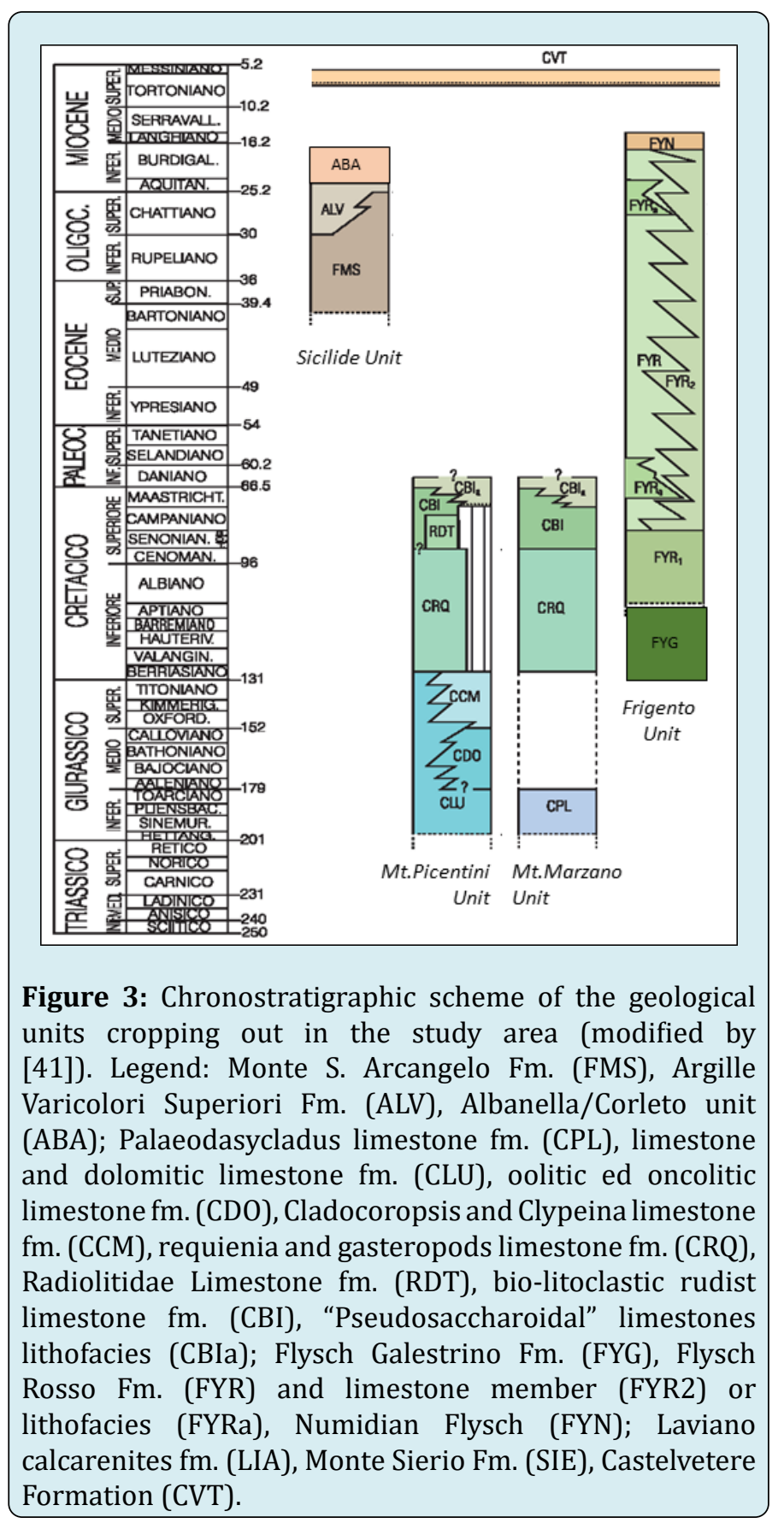




\section{Petroleum \& Petrochemical Engineering Journal}

\section{Methods}

The entire dataset comprises 28 sandstone samples coming from the Corleto, Pre-Numidian and Castelvetere Formations (Figure 4). The modal sandstone composition is determined by point-counting using Gazzi-Dickinson method [42-45] and the grain types are distinguished following Dickinson [45,46], Zuffa [43,44], Critelli and Le Pera [19], Critelli and Ingersoll [47]. In particular, grains are distinguished as follows:

1. Quartz grains, that include monocrystalline quartz $(\mathrm{Qm})$, polycrystalline quartzose fragments $(\mathrm{Qp})$ and total quartzose grains $(\mathrm{Qt}=\mathrm{Qm}+\mathrm{Qp})$

2. Fedspar grains $(\mathrm{F})$, including both plagioclase $(\mathrm{P})$ and K-feldspar (K)

3. Aphanitic lithic fragments (Lt), as sum of volcaninc and metavolcanics (Lv and Lvm), sedimentary (Ls) and metasedimentary (Lm; that includes Lsm as sum of Ls + $\mathrm{Lm}$ ). Carbonate lithic fragments are here included in the Ls field (extrabasinal carbonate grains of Zuffa [42,48]; Critelli S, et al. [29,49], since their common occurrence in the Apenninic sandstones detrital modes.

The petrophysical properties were defined with the Highpressure mercury intrusion. The test was carried out using a
Micromeritics Autopore IV 9520 series apparatus. Sandstone samples were crushed in chunks with sizes of about $2-4 \mathrm{~mm}$ and then dried in oven at a constant temperature of $60^{\circ} \mathrm{C}$ for $24 \mathrm{~h}$. The pressure range was settled from 0.4 psi to 60.000 psi in order to investigate pores with diameter ranging from 400 to $0.003 \mu \mathrm{m}$ according to the Washburn equation [50]. Results comprise physical features like porosity, average pore diameter and also pore size distribution (PSD) graphs. Permeability was determined through the Katz and Thompson [51] method, while micropores were differentiated from nanopores following the Loucks, et al. [52] limit of $1 \mu \mathrm{m}$.

\section{Results}

The petrographical and porosimetric analysis were performed on the main sedimentary formations intercepted by the Pavoncelli-Bis tunnel that also represent the main hypothesized reservoirs for the hydric supply. These formations are characterized by turbiditic sandstone deposits preserved both in the subsurface and on land with greatly exposed outcrops. The investigated formations are: the Corleto, Pre-Numidian/Numidian and Castelvetere Formations (Figures $4 \& 5$ ).

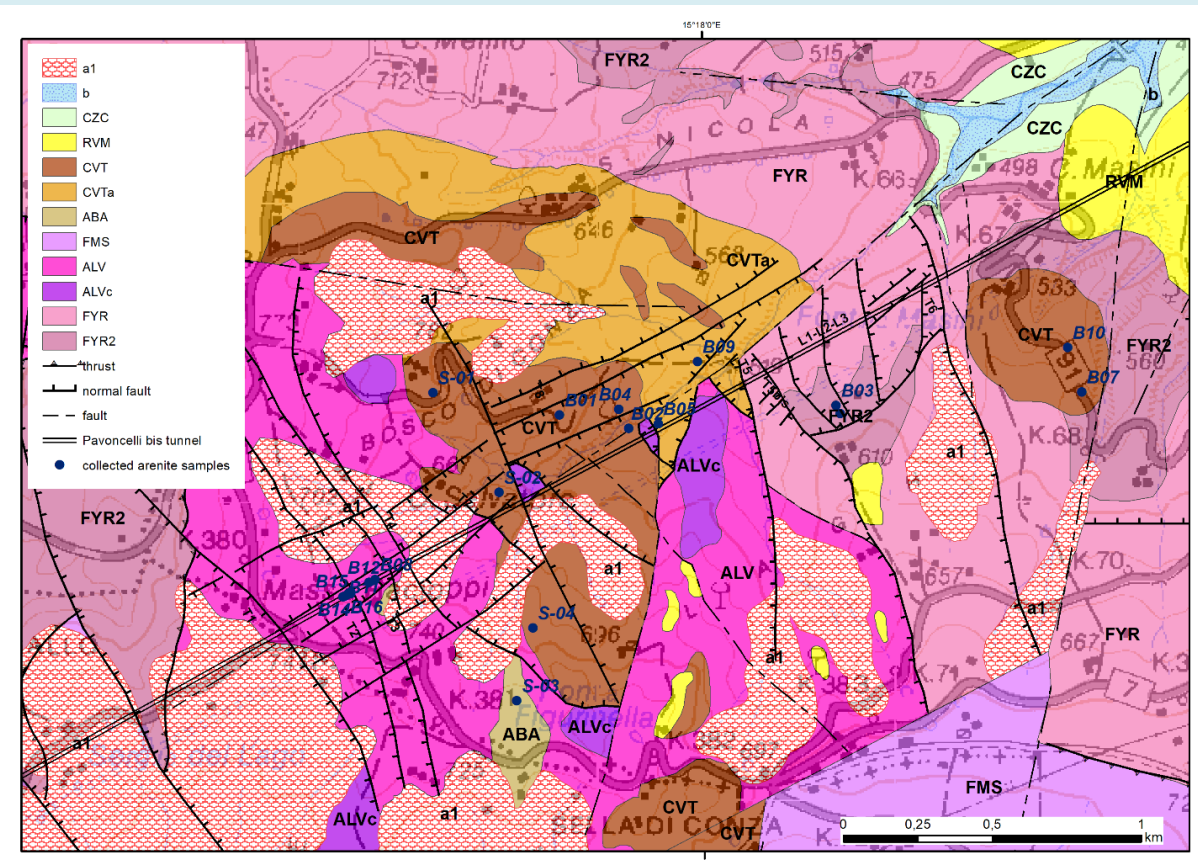

Figure 4: Geological map of the study area, indicating the location of the collected samples. Legend: a) Sicilide unit - Monte S. Arcangelo Fm. (FMS), Argille Varicolori Superiori Fm. (ALV) and calcareous lithofacies (ALVc), Albanella / Corleto unit (ABA); b) Frigento unit - Flysch Rosso Fm. (FYR) and limestone member (FYR2), pre-numidian sequence (FYN); synorogenic units - Castelvetere Formation (CVT) with silty-clayey-marly lithofacies (CVTa), Ruvo del Monte Synthem (RVM); Quaternary units Conza della Campania synthem (CZC), terraced and actual alluvial deposits and alluvial fan (b), landslide deposits (a1). 


\section{Petroleum \& Petrochemical Engineering Journal}

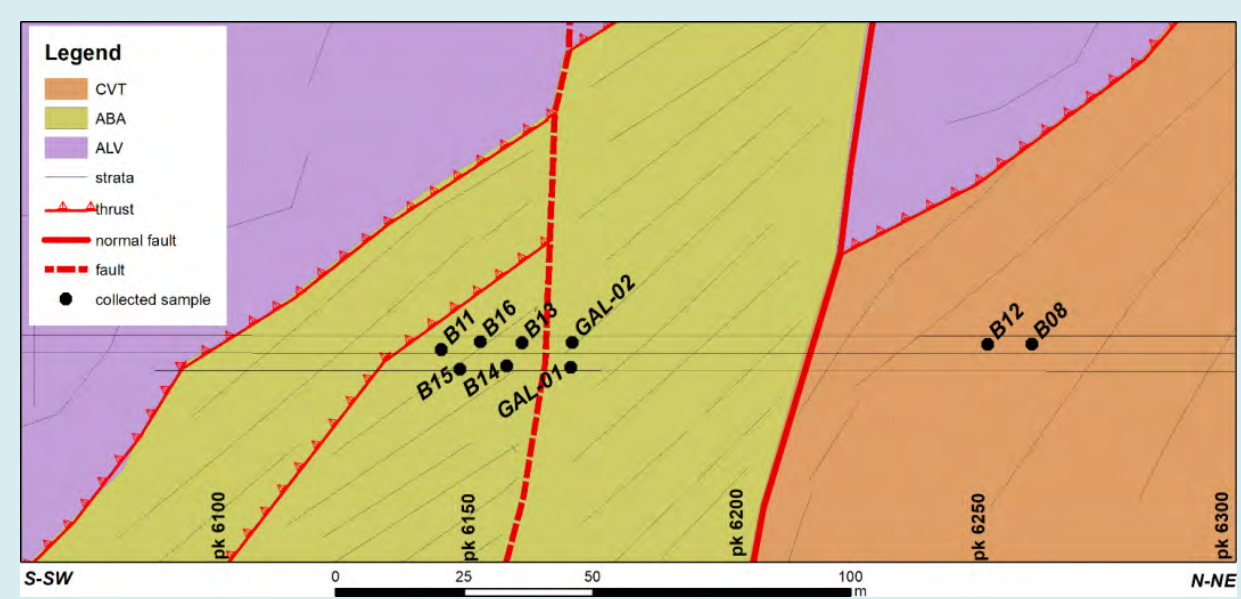

Figure 5: Pavoncelli-bis tunnel section from $6100 \mathrm{~m}$ to $6300 \mathrm{~m}$ chainage (pk) that intercepts the Argille Varicolori Superiori Fm. (ALV), Albanella/Corleto unit (ABA) and Castelvetere Formation (CVT).

\section{Sandstones Composition and Diagenetic Signatures}

Sandstone composition analysis includes 21 sandstone samples that have been collected along stratigraphic sections cropping out in the area located in correspondence with the tunnel segment (Figures 4, 5). Matano, et al. [9] summarized the main compositional signatures (and related raw data of point-counting results) of the selected sandstone suites. The analyzed sandstone samples include the (i) quartzolithic sandstone of the Albanella-Corleto Formation (ABA), (ii) quartzofeldspathic sandstones of the Castelvetere Formation (CVT), and (iii) quartzose and hybrid arenites of the preNumidian and Numidian Sandstone Formation (Figure 6).

Quartzolithic Sandstone Suite: Main Composition and Provenance. The quartzolithic sandstones have abundant quartz and lithic grains (Qm60 F13 Lt26), while feldspar is minor and dominantly plagioclase. Aphanitic lithic fragments (Lm42 Lv31 Ls27) include metavolcanic (serpentinite, to serpentine schist), volcanic (mainly microlithic, and felsitic textures), abundant metasedimentary (phyllite, schist, minor quartzite, and fine-grained schist), and sedimentary (micritic to sparitic limestone grains, and radiolarian chert) grains. The abundant metasedimentary fragments in this petrofacies are derived from the low-to-medium grade metamorphic Paleozoic sections of the Calabrian Terranes $[18,20-22,24-26,53]$. The abundant volcanic lithic fragments are derived from coeval active volcanism located to the west (i.e. Sardinia magmatic arc; [18]) and textures of the volcanic particles suggest an andesitic to dacitic volcanism [54]. Metavolcanic fragments are closely related to accreted oceanic terranes of the Lucanian Oceanic Unit obducted at the time of deposition of the Quartzolithic sandstones of the Corleto Formation [18,53]. Sedimentary detritus can have diverse source terranes from the Mesozoic sedimentary covers of the Paleozoic metamorphic units, and from sedimentary strata of the accreted oceanic terranes, and from the basinal and carbonate platform units of the internal portions of the Apenninic units [18,24-26]. The quartzolithic petrofacies corresponds to the Corleto and Albanella Sandstone Formations (Figure 6).

Diagenetic signatures of quartzolithic sandstone suite: Interstitial component of quartzolithic sandstone suite are mainly composed of carbonate cement (mainly calcite) as pore-filling, patchy calcite and calcite replacement of framework grains. Other authigenic phases consist of illite-kaolinite cements and clay coats and minor quartz overgrowth. Matrix is abundant in the quartzolithic sandstone and consists of siliciclastic fine-matrix and detrital clay minerals and phyllosilicate (Figure 7A). Pseudomatrix is also present as a product of deformation and disaggregation of silt-clay intrabasinal clasts by the action of mechanical compaction. Because of the signature of volcanic detritus in the quartzolithic sandstone, diagenetic alteration of volcanic glass particles and fine ash matrix are common to generate authigenic clays (Figure 7B), Fe-Oxides and pore lining chlorite (Figure 7C).

Quartzofeldspathic sandstone petrofacies: Main Composition and Provenance- The petrofacies has abundant quartz and feldspars (Qm51 F32 Lt15; Figure 6), while lithic fragments are minor. Plagioclase grains are dominant than K-feldspar $(\mathrm{P} / \mathrm{F}=0.83)$. Aphanitic lithic grains include abundant metasedimentary and sedimentary, and minor volcanic, and ophiolitic lithic particles (Lm47Lv7 Ls46). Metasedimentary lithic fragments include abundant phyllite and fine-grained schist. Sedimentary lithic fragments consist of abundant extrabasinal carbonate fragments, 


\section{Petroleum \& Petrochemical Engineering Journal}

mostly Jurassic to Lower Tertiary pelagic and shallowmarine carbonate fragments, and minor radiolarian chert, shale and siltstone fragments. Ophiolitic detritus, includes serpentinite, and serpentine-schist, whereas volcanic lithic fragments are minor and consist of lithic particles that have a felsitic granular texture. Phaneritic rock fragments include plutonic and metamorphic detritus; plutonic detritus consists of dominantly quartz-plagioclase-biotite particles of granodioritic to tonalitic compositions, and minor quartz-Kfeldspar composite grains of granite composition. Phaneritic metamorphic detritus consists of quartz-plagioclasesillimanite, and quartz-plagioclase-garnet-sillimanite composite grains of gneiss and micaschist. The abundant metamorphic and plutonic detritus in the quartzofeldspathic sandstone petrofacies are derived from the metamorphic and plutonic Paleozoic sections of the Calabrian Terranes [17-18,20-22,24-26]. Sedimentary detritus can have diverse source terranes from the Mesozoic sedimentary covers of the Paleozoic metamorphic-plutonic terranes, and from sedimentary strata of the basinal and carbonate platform units of the internal portions of the Apenninic units [18,2426]. Ophiolitic fragments are closely related to thrusted oceanic terranes of the Lucanian Oceanic Unit $[18,53]$. The quartzofeldspathic petrofacies corresponds to the Castelvetere Sandstone Formation.

Diagenetic signatures of quartzofeldspathic sandstone suite: Pore-filling calcite as such patchy calcite cement, occurs mainly in these sandstones, where it occurs as small mosaics or single crystals, which formed as corrosion and grain replacement of siliciclastic grains (mainly feldspar). Patchy calcite cement commonly occurs as iron-rich calcite formed by calcitization of older carbonate cement of ankerite and dolomite. Growth of this cement was probably late, based on its occurrence dominantly in well compacted sandstone. pore-filling kaolin plates are less than $10 \mu \mathrm{m}$ and normally occur close to detrital framework grains. Kaolin sheets commonly appear included in younger carbonate cement. Pore-lining Illite consists of illite clay coats characterized mainly by discontinuous coatings tangentially oriented to grain surfaces. Partial dissolution of feldspar (Figure 7D, E) is the mainly responsible of generation of authigenic clay minerals, minor overgrowths of authigenic feldspars [55] as such as generation of secondary porosity (Figure 7D, E). Siliciclastic and minor carbonate matrix (micrite) are present. Siliciclastic matrix consists of the clay-mineral fraction formed during diagenesis due to several processes. Infiltration of clay minerals is deduced by the presence of illite clay coats, which implies mineral transformation/ recrystallization. In addition, and included as diagenetic matrix, kaolin cement is widely distributed, mainly in pore space of Castelvetere sandstone. Feldspar is sometimes transformed into kaolin (epimatrix), as a result of early kaolinitization by meteoric water. In turn, these minerals transformed during burial into more stable mineral phases (dickite) or other clay minerals (illite).

Hybrid arenite and quartzarenite sandstone petrofacies: Main Composition and Provenance: This petrofacies has abundant quartz (Qm95 F5 Lt0), while feldspar is minor and dominantly plagioclase. Aphanitic lithic fragments are virtually absent or minor. Quartz grains are dominantly monocrystalline, and they are well rounded. Few dense minerals are ultrastable and consist of zircon, tourmaline and routile. Quartzarenite are well cemented by quartz overgrowth and calcite. Hybrid arenites of the pre-Numidian Sandstone Formation are a sub-petrofacies carbonate-rich, including abundant quartz, and extrabasinal carbonate lithic grains. Very abundant intrabasinal carbonate particles of bioclasts (mainly planktonic forams and sponges), and minor peloids and intrabasinal non-carbonate glauconite grains. Abundance of well-rounded quartzose detritus of the pre-Numidian and Numidian Sandstone Formation has been interpreted as a craton-derived huge arrival of sandsized quartz from the African continental margin [18,2022,26,56-58]. The quartzose and hybrid arenite petrofacies corresponds to the pre-Numidian (hybrid arenite) and Numidian Sandstone Formation (quartzarenite) (Figure 6).

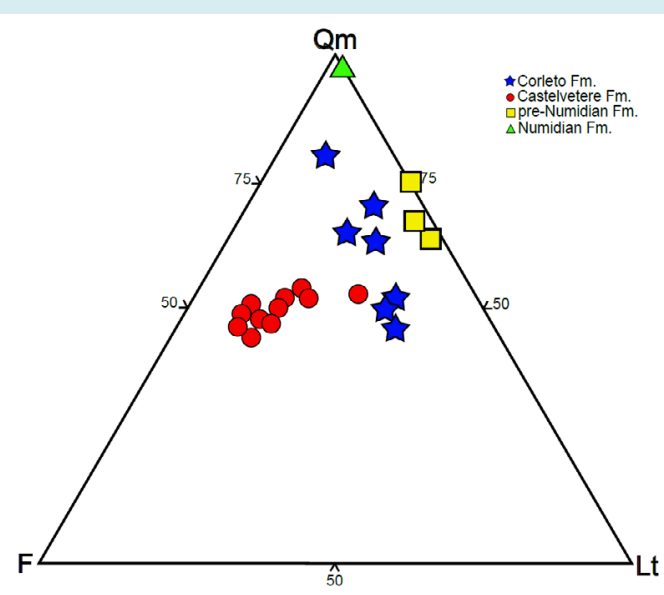

Figure 6: Ternary compositional plot Qm: monocrystalline quartz; F, feldspars (K + P); Lt, aphanitic lithic fragments, of the Corleto, Castelvetere and pre-Numidian and Numidian sandstone formations.

Diagenetic signatures of quartzarenite suite: Several mineral species have been identified as authigenic cement. The key phases are carbonate and silica. Carbonate cements occur widely as authigenic pore-filling calcite or as patchy calcite crystals, and minor replacement of framework grains. These sandstones show evidence of significant silica activity. Pressure solution produced abundant silica that was incorporated into diagenetic waters and was then precipitated as quartz overgrowth cement (Figure 7F, G) 


\section{Petroleum \& Petrochemical Engineering Journal}

[59]. Even if minor, Fe-oxides precipitated around framework grains under oxidizing conditions. The presence of euhedral Fe-oxides around quartz grains suggests that Fe-bearing carbonate formed under reducing geochemical conditions. All these processes acted at low temperature and in an open chemical diagenetic system [60], contemporaneously with mechanical compaction and development of pseudomatrix.
Hybrid arenites of the Pre-Numidian Sandstone include abundant micrite matrix and an early stage of authigenic calcite and Fe-carbonate. Calcitization of Fe-carbonates (early siderites and late Fe-dolomite and ankerite) can be deduced by the presence of euhedral ghost textures and impurities of Fe-oxides (Figure 7H), respectively.
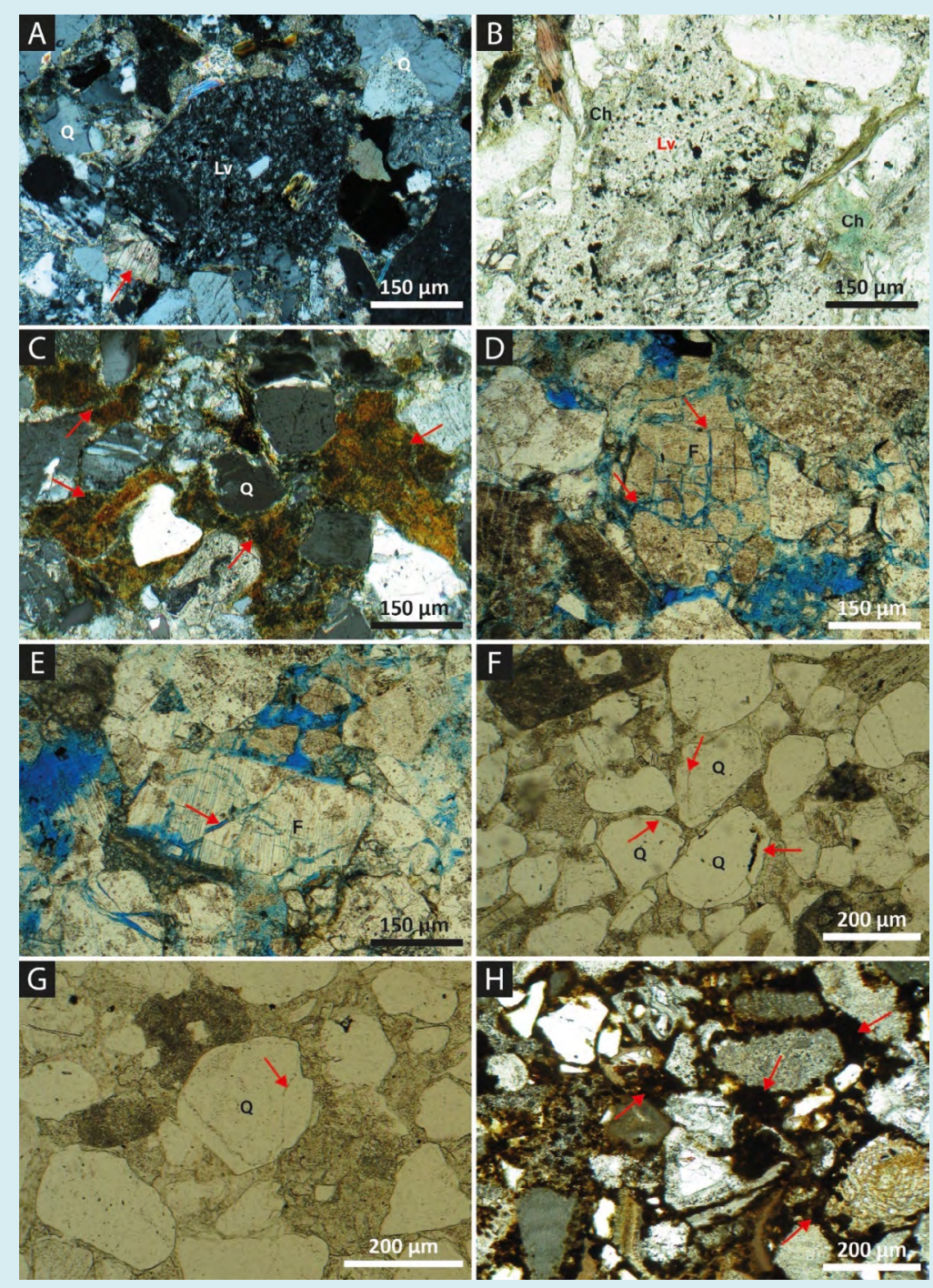

Figure 7: Petrographic features of the main diagenetic features affecting the studied turbiditic sandstones. A-B-C) Corleto Formation: A) Volcanic and metasedimentary lithic fragments of the Corleto sandstone are highly compacted and cemented by patchy calcite, This is testified also by the presence of compenetreted grains related to pressure-solution processes; B) occurrence of authigenic pore-lining chlorite; C) occurrence of clay matrix partially recrystallized of original argillaceous ripup clasts of turbiditic quartzolithic sandstone of the Corleto Formation. D-E) Castelvetere Sandstone Formation: D-E) feldspar dissolution and partially dissolved feldspar grains generating secondary porosity and neoforming authigenic clay minerals. Development of secondary porosity, due to dissolution of feldspar grains, along preferentially dissolution and fracturing surfaces (red arrows); F-G-H) Numidian and Pre-Numidian Sandstone Formation: (F-G) abundant authigenic quartz overgrowth (red arrows) in well sorted Numidian quartzarenites. H) Hybrid arenites carbonate-rich of the pre-Numidian sandstone Formation include abundant early-cemented Fe-carbonate cements, partially dissolved during late diagenesis producing calcite and FeOxides (red arrow). 


\section{Petroleum \& Petrochemical Engineering Journal}

\section{Porosimetry Analysis}

Corleto Formation: The Corleto Formation sandstone samples (16 in total) show porosity values ranging from 0.7 $\%$ to $8.3 \%$, with the average of $4.74 \%$, the median of $4.56 \%$ and a standard deviation of 2.46 (Table1).

Permeability has a wider range of variation, since it spans from $1.43 \mathrm{mD}$ to $779.58 \mathrm{mD}$; the average is $215.34 \mathrm{mD}$, the median is $181.70 \mathrm{mD}$, the standard deviation reaches 210.02 (Table 1). However, within the Corleto dataset only 5 samples are characterized by permeability values higher than $300 \mathrm{mD}$ (17SC-1028, 17SC-1030A, 17SC-1032, 17SC1034, 17SC1035). If we exclude these samples, the average goes to $102.50 \mathrm{mD}$; the median to $92.52 \mathrm{mD}$; the standard deviation greatly reduces to 91.31 .

The average pore diameter values show again a very wide spectrum of variation between $0.06 \mu \mathrm{m}$ and $62.38 \mu \mathrm{m}$; the average is $4.30 \mu \mathrm{m}$; the median is $0.13 \mu \mathrm{m}$; the standard deviation is 15.50 (Table 1). Like permeability, also in this case, only three samples show values greater than $0.3 \mu \mathrm{m}$ (17SC-1030A, 17SC-1030B, B-15) and they are responsible for the great difference between the average and median values and for the high standard deviation. Excluding these samples from the computation we obtain an average value of $0.13 \mu \mathrm{m}$; median value of 0.12 ; a standard deviation reduced to 0.05 .

Plots of log differential intrusion $(\mathrm{mL} / \mathrm{g})$ vs pore diameter $(\mu \mathrm{m})$ show for the entire dataset a constant topology of the curves characterized by a common major peak centered in proximity of the $1 \mu \mathrm{m}$ value, with the secondaries shifted to higher pore size values of $100 \mu \mathrm{m}$ or higher (Figure 8). According to the principal peak location, the sample could be characterized by a preponderance of nanopores (if the principal peak is below the $1 \mu \mathrm{m}$ limit), as happens for the 17SC-1027 and 17SC-1029 samples (Figure 8); or alternatively could be dominated by micro+mesopores (if the principal peak is in proximity or above the $1 \mu \mathrm{m}$ limit), as happens for the 17SC-1031 and 17SC-1038 samples (Figure 8).

Finally, plots of total intrusion (\%) vs pore diameter $(\mu \mathrm{m})$, further confirm that the analyzed sandstone samples of the Corleto Formation are characterized by nanopores and micro+mesopores with a variable relative distribution of these two types of pores (Figure 9). Data suggest a presence of nanopores variable between $0 \%$ and $71 \%$, with an average of $40 \%$ and a median of $44 \%$, the standard deviation is 21.56. This testifies the general dominance of micro+mesopores on the nanopores, in fact only 4 samples (17SC-1027, 17SC-1028, 17SC-1029, B-15) show a nanopore volume higher than $50 \%$.

\begin{tabular}{|c|c|c|c|c|c|}
\hline Sample & $\begin{array}{c}\text { Porosity } \\
\mathbf{( \% )}\end{array}$ & $\begin{array}{c}\text { Permebility } \\
(\mathbf{m D})\end{array}$ & $\begin{array}{c}\text { Average Pore } \\
\text { Diameter }(\boldsymbol{\mu m})\end{array}$ & $\begin{array}{c}\text { Micro + Mesopores } \\
\text { Volume (\%) }\end{array}$ & $\begin{array}{c}\text { Nanopores Volume } \\
\mathbf{( \% )}\end{array}$ \\
\hline 17SC-1026 & 3,917 & 234,207 & 0,119 & 52,41 & 47,59 \\
\hline 17SC-1027 & 3,236 & 25,361 & 0,071 & 32,58 & 67,42 \\
\hline 17SC-1028 & 8,150 & 429,222 & 0,103 & 43,37 & 61,18 \\
\hline 17SC-1029 & 2,655 & 171,734 & 0,102 & 38,82 & 10,47 \\
\hline 17SC-1030A & 1,137 & 409,264 & 2,367 & 89,53 & 0 \\
\hline 17SC-1030B & 0,709 & 194,666 & 62,380 & 100 & 45,14 \\
\hline 17SC-1031 & 4,868 & 92,524 & 0,210 & 54,86 & 47,06 \\
\hline 17SC-1032 & 6,423 & 338,737 & 0,117 & 52,94 & 27,4 \\
\hline 17SC-1033 & 4,256 & 36,407 & 0,134 & 55,84 & 41,05 \\
\hline 17SC-1034 & 8,305 & 779,584 & 0,244 & 72,6 & 39,9 \\
\hline 17SC-1035 & 7,421 & 361,117 & 0,122 & 58,95 & 32,9 \\
\hline 17SC-1036 & 5,131 & 5,104 & 0,175 & 60,1 & 47,92 \\
\hline 17SC-1037 & 7,118 & 173,689 & 0,139 & 67,1 & 71,7 \\
\hline 17SC-1038 & 3,687 & 189,728 & 0,164 & 52,08 & 0 \\
\hline B-13 & 6,980 & 2,696 & 0,066 & 28,3 & 40,03 \\
\hline B-15 & 1,887 & 1,432 & 2,403 & 100 & 44,65 \\
\hline Average & 4,742 & 215,342 & 4,307 & 59,97 & 21,569 \\
\hline Median & 4,562 & 181,708 & 0,136 & 55,35 & 21,569 \\
\hline Standard Dev. & 2,466 & 210,023 & 15,505 & & \\
\hline
\end{tabular}

Table 1: Samples coming from sandstones of the Corleto Formation, used for mercury intrusion porosimetry analysis. 


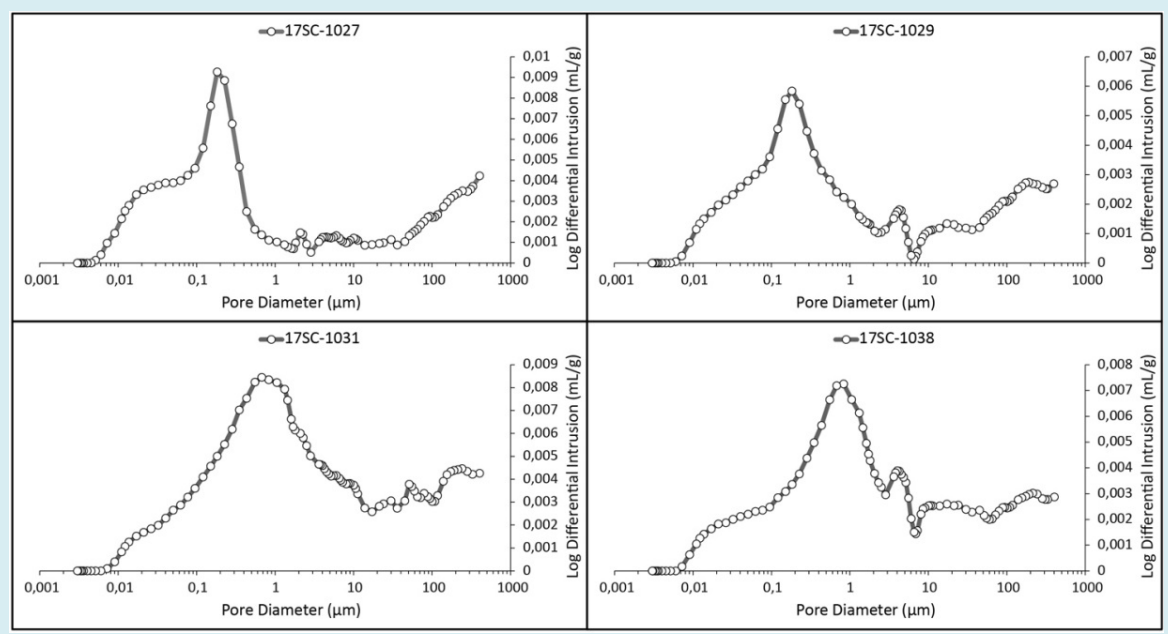

Figure 8: Cross-plot of pore diameter $(\mu \mathrm{m})$ versus log differential intrusion $(\mathrm{mL} / \mathrm{g})$ for 4 representative samples of the Corleto Formation. The general distribution of pores is plurimodal with a principal peak that can be highly below the $1 \mu \mathrm{m}$ limit (17SC1027, 17SC-1029), or in proximity/above the $1 \mu \mathrm{m}$ limit (17SC-1031, 17SC-1038).

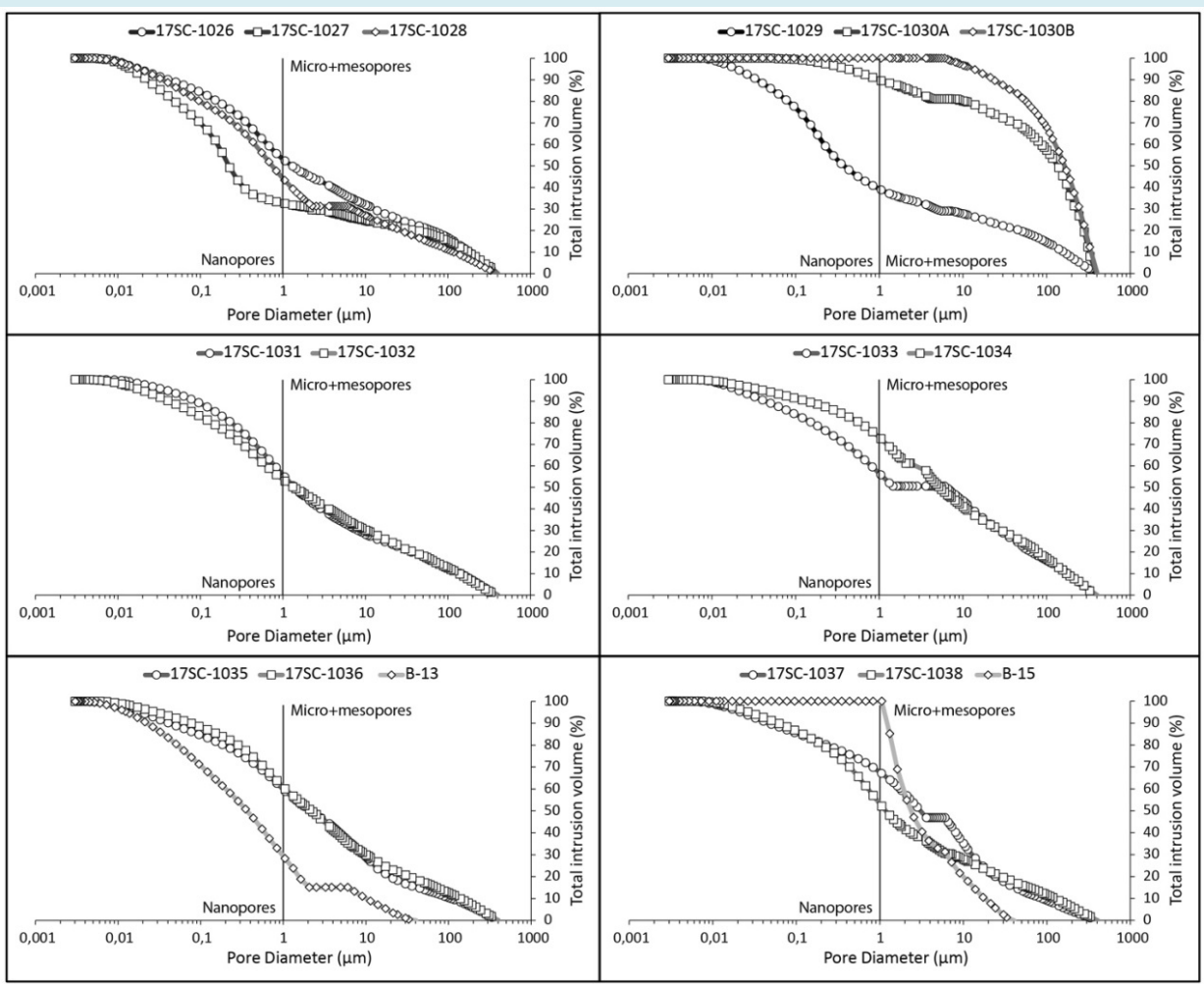

Figure 9: Cross-plot of pore diameter $(\mu \mathrm{m})$ versus total intrusion volume $(\%)$ of all the studied Corleto Formation samples. Micro+mesopores volume is generally dominant in respect of the nanopores volume (except for the 17SC-1027, 17SC-1028, 17SC-1029 samples).

Pre-Numidian sandstones Formation: For the Prenumidian sandstones Formation, 6 representative samples have been analyzed through the mercury intrusion porosimetry. Porosity ranges between $1.43 \%$ and 13.03 $\%$; the average is $5.04 \%$; median is $3.94 \%$; the standard deviation is 4.27 (Table 2). Permeability varies from $0.58 \mathrm{mD}$ to $287.52 \mathrm{mD}$; the average is $130.22 \mathrm{mD}$; the median 122.25 $\mathrm{mD}$; the standard deviation is 121.35 (Table 2).

The average pore diameters are limited to values below 
$0.2 \mu \mathrm{m}$, between $0.02 \mu \mathrm{m}$ and $0.16 \mu \mathrm{m}$; the average is 0.06 $\mu \mathrm{m}$; the median $0.042 \mu \mathrm{m}$; the standard deviation is 0.052 (Table 2). The plots of log differential intrusion $(\mathrm{mL} / \mathrm{g})$ vs pore diameter $(\mu \mathrm{m})$ show the presence of both unimodal and plurimodal trends (Figure 10). The 17SC-1039 and 17SC-1041 samples show a unimodal curve with the principal peak located at diameter of $0.02 \mu \mathrm{m}$ suggesting a sample dominated by nanopores (Figure 10). Whereas the 17SC-1040 and 17SC-1042 samples are characterized by a plurimodal trend with the major peaks shifted to values of $10 \mu \mathrm{m}$ (17SC-1042) or above the $300 \mu \mathrm{m}$ (17SC-1040) indicating the dominance of micro+mesopores (Figure 10). The dominance of a dimensional class (e.g. nanopores) on the other is further confirmed by the plots of total intrusion $(\%)$ vs pore diameter $(\mu \mathrm{m})$ (Figure 11) and by data in Table 2 in which the 17SC-1039 and 17SC-1041 samples are both characterized by $77 \%$ of nanopores; whereas in the 17SC1042 and 17SC-1039 samples nanopores volume spans from $37 \%$ and $29 \%$. Considering all the dataset, the average value for the nanopore volume is $66 \%$; the median is $77 \%$; the standard deviation is 26.78 .

\begin{tabular}{|c|c|c|c|c|c|}
\hline Sample & $\begin{array}{c}\text { Porosity } \\
(\mathbf{\%})\end{array}$ & $\begin{array}{c}\text { Permebility } \\
(\mathbf{m D})\end{array}$ & $\begin{array}{c}\text { Average pore Diameter } \\
(\boldsymbol{\mu m})\end{array}$ & $\begin{array}{c}\text { Micro + Mesopores Volu- } \\
\mathbf{m e}(\mathbf{\%})\end{array}$ & $\begin{array}{c}\text { Nanopores Volume } \\
(\mathbf{\%})\end{array}$ \\
\hline 17SC-1039 & 1,864 & 92,458 & 0,023 & 22,87 & 77,13 \\
\hline 17SC-1040 & 1,431 & 152,048 & 0,068 & 62,68 & 37,32 \\
\hline 17SC-1041 & 4,540 & 247,068 & 0,026 & 22,86 & 77,14 \\
\hline 17SC-1042 & 6,064 & 287,528 & 0,161 & 70,95 & 29,05 \\
\hline B-03 & 3,340 & 0,588 & 0,043 & 7,20 & 92,80 \\
\hline B-06 & 13,030 & 1,651 & 0,040 & 13,10 & 86,90 \\
\hline Average & 5,045 & 130,223 & 0,060 & 33,28 & 66,72 \\
\hline Median & 3,940 & 122,253 & 0,042 & 22,87 & 77,14 \\
\hline Standard Dev. & 4,270 & 121,356 & 0,052 & 26,787 & 26,787 \\
\hline
\end{tabular}

Table 2: Samples coming from Pre-Numidian sandstones, used for mercury intrusion porosimetry analysis.

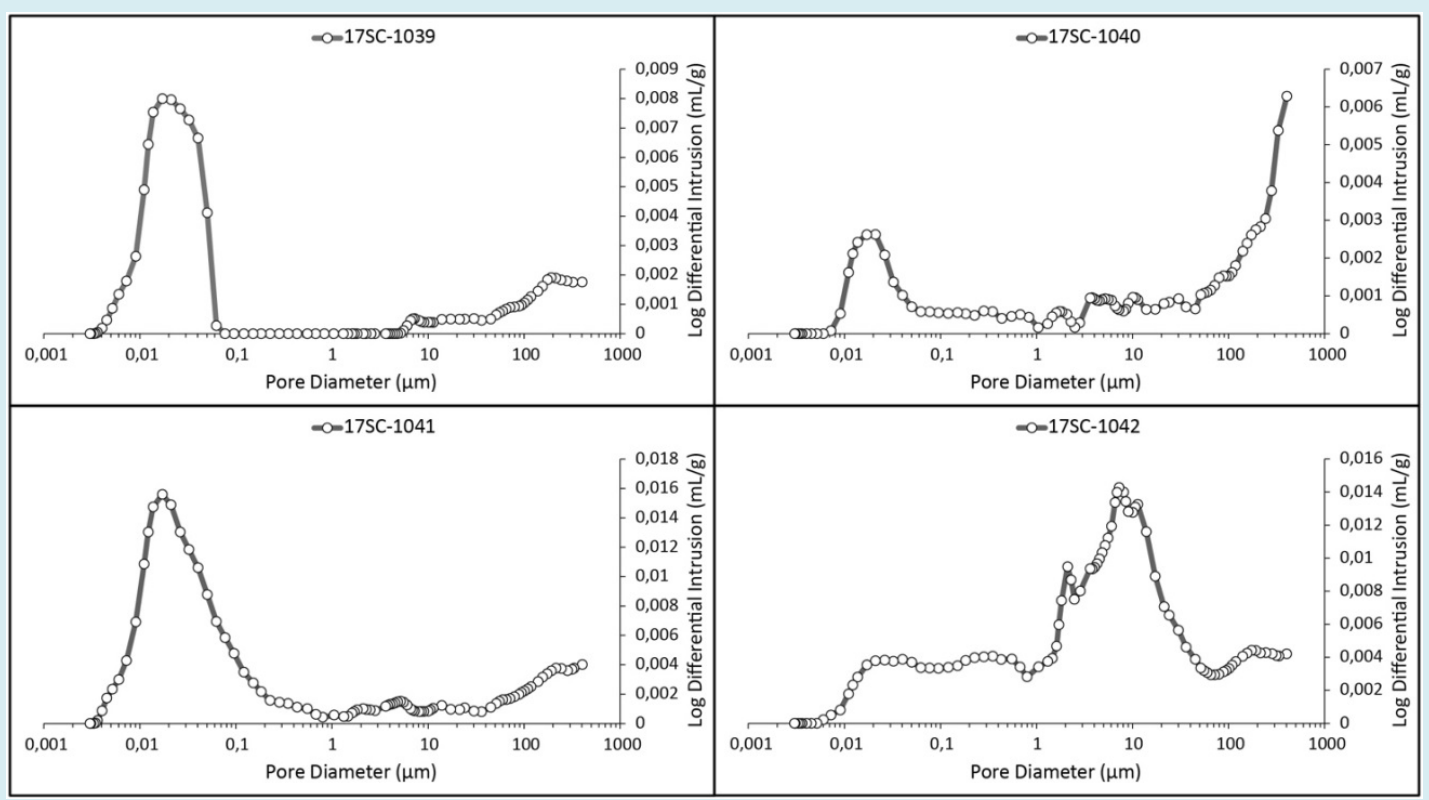

Figure 10: Cross-plot of pore diameter $(\mu \mathrm{m})$ versus log differential intrusion $(\mathrm{mL} / \mathrm{g})$ for the 4 samples of the Pre-numidian sandstones. The 17SC-1039 and 17SC-1041 samples show a unimodal trend with the principal peak located in the nanopores dimensional class. The $17 \mathrm{SC}-1040$ and $17 \mathrm{SC}-1042$ samples are characterized by a plurimodal trend with the major peaks shifted in the micro+mesopores dimensional classes. 


\section{Petroleum \& Petrochemical Engineering Journal}

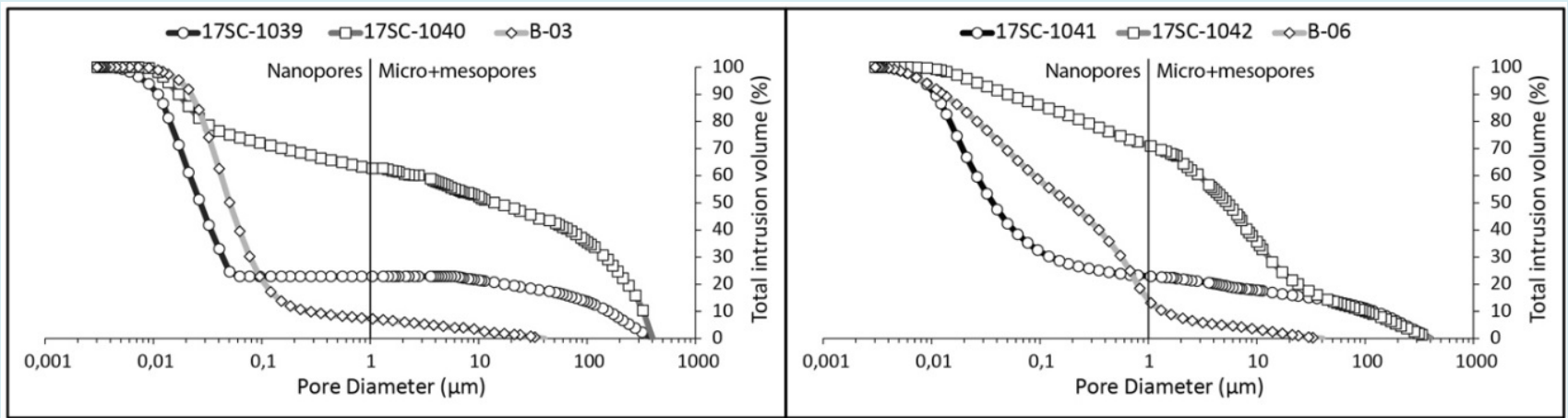

Figure 11: Cross-plot of pore diameter $(\mu \mathrm{m})$ versus total intrusion volume $(\%)$ of all the studied Pre-numidian sandstone samples. 17SC-1039, 17SC-1041, B-03, B06 are dominated by nanopores, 17SC-1040 and 17SC-1042 are dominated by micro+mesopores.

Castelvetere Formation: A total of 6 sandstone samples coming from the Castelvetere Formation have been analyzed. Porosity spans from $6.41 \%$ to $25.58 \%$; the average is 11.66 $\%$; median is $9.58 \%$; standard deviation is 6.96 (Table 3). However, only one sample (B-01) show a porosity value much higher than the others, reaching $25.58 \%$. Excluding this sample from the computation, the average changes in $8.88 \%$; the median goes to $9.22 \%$, similar to the previous one; and the standard deviation is greatly reduced to 1.60 .

Permeability is characterized by very low values and, unlike the Corleto and Pre-Numidian suites, shows a very limited range of variation. It is comprised between $2.79 \mathrm{mD}$ and $9.05 \mathrm{mD}$; the average is $5.66 \mathrm{mD}$; the median is $4.84 \mathrm{mD}$; the standard deviation is 2.68 (Table 3). The average pore diameter ranges between $0.039 \mu \mathrm{m}$ to $0.179 \mu \mathrm{m}$; average is
$0.119 \mu \mathrm{m}$; median is $0.114 \mu \mathrm{m}$; standard deviation is 0.053 (Table 3).

Plots of $\log$ differential intrusion $(\mathrm{mL} / \mathrm{g})$ vs pore diameter $(\mu \mathrm{m})$ show for the entire dataset the presence of both plurimodal (e.g. B-05, B-10) and generally unimodal (e.g. B-02, B-08) trends (Figure 12), with the principal and secondary peaks variably located both on the nanopores and micro+mesopores dimensional classes. This is supported by the plots of total intrusion (\%) vs pore diameter $(\mu \mathrm{m})$ (Figure 13) and by the data in Table 3. Particularly, in the Castelvetere Formation analyzed dataset, two samples are dominated by nanopores, whereas the remaining 4 are dominated by micro+mesopores. Nanopores volume ranges between $30 \%$ and $60 \%$, the average is $44 \%$; the median is $43 \%$; the standard deviation is 12.43 .

\begin{tabular}{|c|c|c|c|c|c|}
\hline Sample & $\begin{array}{c}\text { Porosity } \\
(\mathbf{\%})\end{array}$ & $\begin{array}{c}\text { Permebility } \\
(\mathbf{m D})\end{array}$ & $\begin{array}{c}\text { Average Pore Diameter } \\
(\boldsymbol{\mu m})\end{array}$ & $\begin{array}{c}\text { Micropores Volume } \\
\mathbf{( \% )}\end{array}$ & $\begin{array}{c}\text { Nanopores Volume } \\
(\mathbf{\%})\end{array}$ \\
\hline B_01 & 25,582 & 9,056 & 0,120 & 69,5 & 30,5 \\
\hline B_02 & 9,223 & 8,854 & 0,095 & 66,7 & 33,3 \\
\hline B_04 & 6,413 & 4,414 & 0,179 & 56,8 & 43,2 \\
\hline B_05 & 10,516 & 5,277 & 0,039 & 39,1 & 60,9 \\
\hline B_08 & 9,942 & 3,593 & 0,175 & 56,1 & 43,9 \\
\hline B_10 & 8,338 & 2,792 & 0,108 & 42 & 58 \\
\hline Media & 11,669 & 5,664 & 0,119 & 55,03 & 44,97 \\
\hline Mediana & 9,582 & 4,846 & 0,114 & 56,45 & 43,55 \\
\hline $\begin{array}{c}\text { Dev. } \\
\text { Standard }\end{array}$ & 6,966 & 2,681 & 0,053 & 12,437 & 12,437 \\
\hline
\end{tabular}

Table 3: Samples coming from sandstones of the Castelvetere Formation used for mercury intrusion porosimetry analysis. 


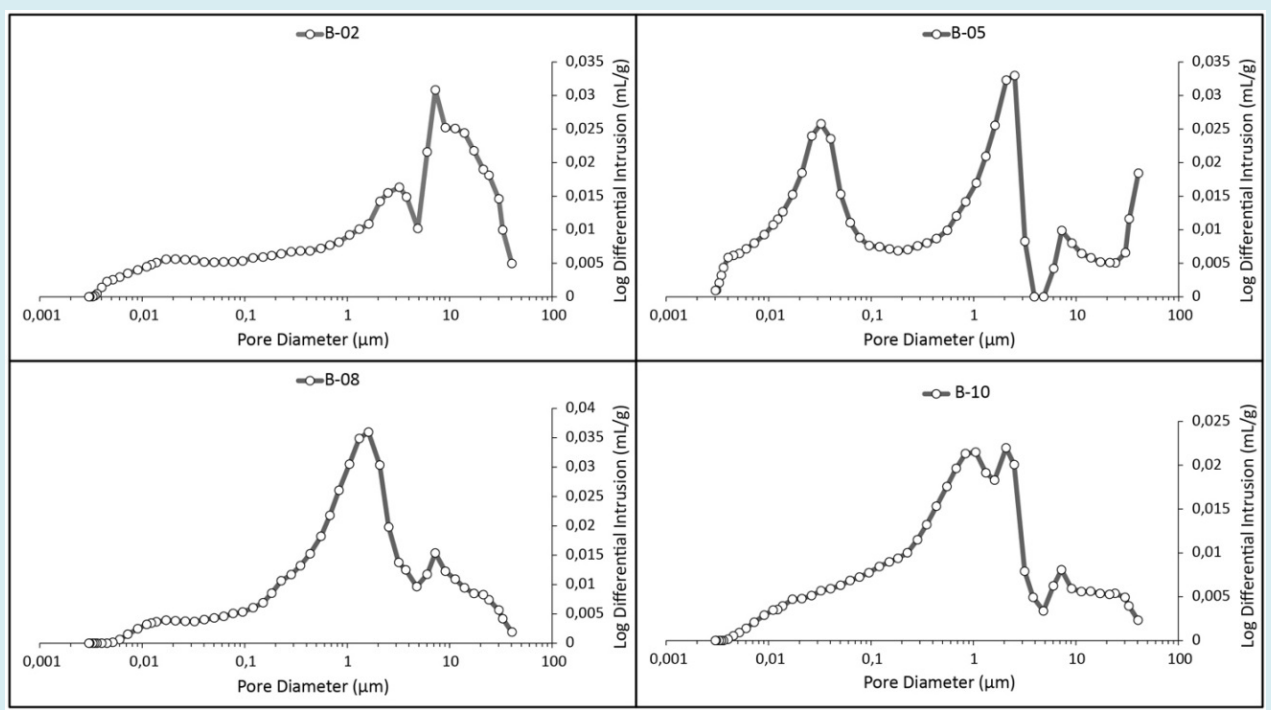

Figure 12: Cross-plot of pore diameter $(\mu \mathrm{m})$ versus log differential intrusion $(\mathrm{mL} / \mathrm{g})$ for the 4 most representative samples of the Castelvetere Formation. The analyzed samples show the presence of both plurimodal and unimodal curves with the principal and secondary peaks located both on the nanopores and micro+mesopores dimensional classes.

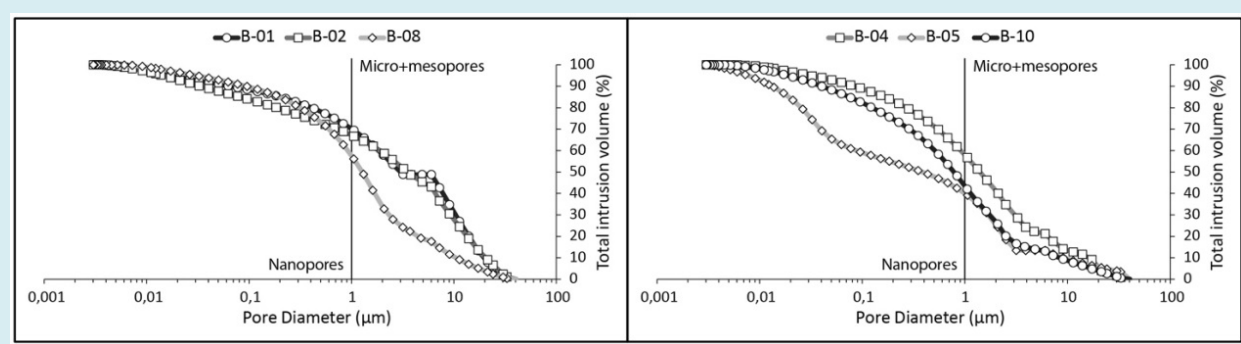

Figure 13: Cross-plot of pore diameter $(\mu \mathrm{m})$ versus total intrusion volume (\%) of all the studied Castelvetere Formation samples. As supported by the data in Table 3, seven samples are dominated by micro+mesopores, the remaining three are dominated by nanopores.

\section{Discussions}

The studied petrophysical parameters (e.g. porosity, permeability, average pore diameter, nanopores volume) highlighted an intrinsic variability among the three studied formations (Corleto, Pre-Numidian/Numidian and Castelvetere formations), that are all represented by turbiditic arenites deposits with a different petrographic composition (see below).

Porosity is generally low since it reaches a maximum of $11.66 \%$ in average (A) and $9.58 \%$ in median (M) in the Castelvetere $\mathrm{Fm}$. and it assumes also lower values in the Corleto Fm. (4.74 \% in A, $4.56 \%$ in M) and in the PreNumidian Fm. (5.04 \% in A, $3.94 \%$ in M) (Tables 1-3). Permeability is instead generally quite high since it reaches in the Corleto Fm. 215.34 mD in A and $181.70 \mathrm{mD}$ in $\mathrm{M}$ and in the Pre-Numidian Fm. $130.22 \mathrm{mD}$ in A and $122.25 \mathrm{mD}$ in $\mathrm{M}$ (Tables 1 \& 2). This time, the Castelvetere Fm., that presents the highest values of porosity, is characterized by the lowest measured permeability that assumes values of only $5.66 \mathrm{mD}$ in $\mathrm{A}$ and $4.84 \mathrm{mD}$ in $\mathrm{M}$ (Table 3). The average pore diameters are generally low in all the formations (Tables 1-3) since, considering the $\mathrm{M}$ values, it is always below the $0.2 \mu \mathrm{m}$ limit. However, the A show sharp variations, in fact in the Corleto Fm. reaches $4.30 \mu \mathrm{m}$. The differences between the average (A) and median (M) values is present not only in the average pore diameters dataset, but also in permeability and porosity (in this latter case, it is more limited). This is due to the presence of samples with extremely different values compared with the general trend of the formation of which they belong (that can be considered a background), as testified also by high values of the standard deviations (SD). If we consider the Corleto suite, three samples show an average pore diameter that is clearly higher than the other thirteen samples, of one or two orders of magnitude (e.g. $2.36 \mu \mathrm{m}$ in the $17 \mathrm{SC}-1030 \mathrm{~A}, 2.40 \mu \mathrm{m}$ in the B-15 and $62.38 \mu \mathrm{m}$ in the 17SC-1030B). Excluding these three samples 


\section{Petroleum \& Petrochemical Engineering Journal}

from the final computation of the average (A) and median $(\mathrm{M})$, there is a change of the average from $4.30 \mu \mathrm{m}$ to $0.13 \mu \mathrm{m}$ and the median from $0.13 \mu \mathrm{m}$ to $0.12 \mu \mathrm{m}$, with the standard deviation that is considerably reduced from 16.59 to 0.05 (See chapter 4.2.1). As can be seen, the A changes a lot, but the $\mathrm{M}$ remains slightly the same. This brought us to consider for the petrophysical parameters comparison, especially with the petrographical data (see below), the $M$ values. For simplicity, from now-on the adjective median will be omitted in the description of porosity, permeability, average pore diameter and nanopore volume, but it is highlighted in the different plots (Figures 14-16).

The comparison among the different analyzed samples highlighted the absence of a clear trend between porosity and permeability in both the Corleto Formation and the Pre-Numidian Formation, unlike the Castelvetere Formation that shows a positive linear trend $\left(\mathrm{R}^{2}=0.40\right)$ (Figure 14A). The porosity vs permeability comparison moreover shows the presence of two well differentiated clusters of samples (Figure 14A). One, composed by the Corleto Fm. and the PreNumidian Fm., is characterized by high permeability and low porosity values; the other represented by the Castelvetere Fm., is characterized by high porosity and very low permeability values. These clusters are clearly highlighted in the median porosity vs median permeability graph (Figure 14B). Similar relations cannot be traced out in the comparison of the average pore diameter with both porosity and permeability, since no specific trends are present (Figures 15A, B), however a clear differentiation of the two abovementioned clusters is still visible, testifying that permeability, more than porosity is responsible for this differentiation (Figure 15B). Nanopores, represent an important dimensional class for the studied deposits and they dominate on the micro+mesopores in different samples (Tables 1-3). However, no good correlations exist between the nanopores and both porosity and permeability (Figure 15C, D); only the Castelvetere Formation, present a moderate negative trend indicating that permeability is negatively affected by the nanopore presence (Figure 15D). The nanoscale pore network, received a renewed research attention in the last decade since they deeply contributed to the productivity of unconventional reservoirs [61-64]. In particular, nanometer-scale pores are, generally, the dominant pore-fraction in shales and mudrocks [65], enhancing the hydrocarbon storage capacity and fluid transmissivity [66], but they can play an important role also in carbonate and dolomitic rocks [13-14] because of the presence (in various quantity) of intra- and intercrystalline pores and pores within the organic matter [52]. In the studied samples, nanopores do not provide the same improvement of the petrophysical parameters and this is due to the intrinsic nature of the sediments. In fact, all the three studied formations are represented by turbiditic deposits, dominantly composed by fine to relatively coarse sandstones with micro- to meso-scale intercrystal pores, and with a finer fraction, characterized by clays with few amounts of organic matter, that consequently cannot substantially contribute pore network improvement.

To better define the main processes that influenced the petrophysical parameters of the studied sandstones, were compared to the compositional signatures. In particular, porosity and permeability are compared with the average of the three end members of the Dickinson [45-46] classification $(\mathrm{Qm}, \mathrm{F}, \mathrm{Lt})$. For this comparison the Qm (monocrystalline quartz) is more reliable than the $\mathrm{Qt}$ (total quartz), since the petrographical observations highlighted that the diagenetic effect of quartz cementation and overgrowth (see below) preferentially occur with the monocrystalline quartz. Quartz $(\mathrm{Qm})$ is dominant in the Pre-Numidian and Corleto formations, since it reaches $95 \%$ in the first and $61 \%$ in the second, whereas in the Castelvetere Formation it reaches only the $51 \%$. Feldspars (F), are very abundant in the Castelvetere Formation with a total amount of $34 \%$, while in the Corleto Formation and the Pre-Numidian Formation they are respectively present for the $13 \%$ and $5 \%$. Lastly the lithic fragments (Lt) reach a maximum of $26 \%$ in the Corleto Fm., in the Catselvetere Fm. they account for the $15 \%$, while in the Pre-Numidian Fm. they are totally absent. In order to define the presence of any correlation between the petrophysical and petrographical parameters, Qm, F and Lt were compared with porosity and permeability (Figure 16). From the different plots, porosity can be correlated with Qm and F, but not with Lt. In particular, porosity is negatively correlated to the abundance of quartz $(\mathrm{Qm})$ since to an increase in this latter, correspond a decrease in the porosity values (Figure 16A). Instead, feldspars are positively correlated with porosity (Figure 16C) since to an increase of them correspond an increase in porosity. The Lt values are sparse and do not show any specific trend testifying the absence of any correlation with porosity (Figure 16E). Permeability does not show any specific trend with Qm (Figure 16B), F (Figure 16D) and Lt (Figure 16F) since the arrangement of values is generally chaotic, consequently, no correlations are possible. These relations highlighted that the presence of feldspars could enhance the porosity, while the quartz could be responsible for porosity decreasing.

Both quartz and feldspars are widely studied for the reservoir quality characterization, especially for the water and hydrocarbon exploitation [67-70]. Quartz generally results a worsening parameter for porosity, since during diagenesis, the common formation of quartz cementation (occluding quartz) or quartz overgrowth greatly reduces (loss) the porosity in sandstones [71]; moreover, its formation is strongly affected by temperature, since it can be a major cement in rocks that have been heated above the $80^{\circ} \mathrm{C}$ [69]. In an active tectonic context such as the Apennine chain 


\section{Petroleum \& Petrochemical Engineering Journal}

development during the Cenozoic, different burial histories affected the studied formations before being exhumated. This is highlighted by petrology that, in the Pre-Numidian and Corleto formations, revealed the presence of enhanced quartz cementation (quartz overgrowth) (Figure 7F, G). These formations are also the ones with the greater detrital quartz percentage, indicating that the sandstones with more detrital quartz are more prone to the development, if buried and heated above the $80^{\circ} \mathrm{C}$, of diagenetic quartz cementation and overgrowth that reduce porosity. In the Castelvetere Formation, despite the quartz is present with an important volume (51\%), quartz cementation is limited or absent.

Unlike quartz, feldspars are known for their contribution in forming voids and so enhancing porosity in sandstones (in some cases, also of a significant amount) through their dissolution during diagenesis [72-75]. The dissolution of feldspars can occur in different ways, one of the most common process (also occurring in the studied case) states that in response to the feldspar dissolution, new clay minerals and authigenic quartz are formed [72,73]. Whereas the simple solution leaving empty voids is a very rare situation [72] and does not reasonably occur in the studied samples. Particularly, the Castelvetere Formation (quartzofeldspathic arenites) that presents the highest amount of feldspar grains, show an intense feldspar dissolution with the presence of authigenic clay (Figure 7D, E), but few or very uncommon presence of quartz cementation and/or overgrowth. On the contrary, as stated above, the Corleto and Pre-Numidian formations (respectively quartzolithic and quartzarenite) are characterized by abundant quartz overgrowth, with very limited feldspar grains. According to the composition analysis, in the Castelvetere Formation, feldspar dissolution seems to be coupled with the formation of new clay minerals that can also fill the voids left by feldspar dissolution. These clay minerals (e.g. kaolinite) are generally characterized by a good porosity, however their pore network is badly connected since the majority of the pores are isolated or blind. As result, if the formation of clay minerals results in the improvement of the porosity (since a new amount of pore space is created), the permeability results negatively influenced since the new formed pores (isolated or blind) cannot account new permeable pathways in the pore network. This is the reason why the Castelvetere Formation is characterized by the best porosity and worst permeability values (Figure 16B) and why porosity is positively correlated with the amount of feldspars (Figure 16C) and negatively correlated with the amount of quartz (Figure 16A). Moreover, feldspar dissolution should have resulted also in the formation of authigenic quartz, however in the Castelvetere Formation it results minor or absent. This could be explained through two main processes that could be both valid. One regards the burial history of the Castelvetere Formation, that (unlike the Corleto and Pre-Numidian sandstones) were possibly buried to shallower depth that did not permitted the instauration of the suitable conditions for the authigenic quartz formation. The second hypothesis regards a diagenetic process that occurred in the Castelvetere Formation and not in the Corleto and Pre-Numidian formations. In fact, because of the great dissolution of feldspars, the new authigenic clay occluded the pore spaces giving no chance to quartz cementation, and also coated the quartz grains inhibiting the overgrowth process.

In conclusion, the detrital composition of the samples demonstrated to greatly influence the petrophysical properties of the studied turbiditic sandstones, since it created different conditions for the diagenetic processes and so far for the creation or occlusion of pores. Particularly, the quartz dominated sandstones, characterized by few amounts of feldspars, prompted an occlusion of the pore network because of spreading of quartz cementation and overgrowth during diagenesis. On the contrary, the sandstones with a good amount of feldspar grains, were more prone to their dissolution and to the creation of new clay minerals that both increased porosity and potentially inhibited quartz overgrowth.

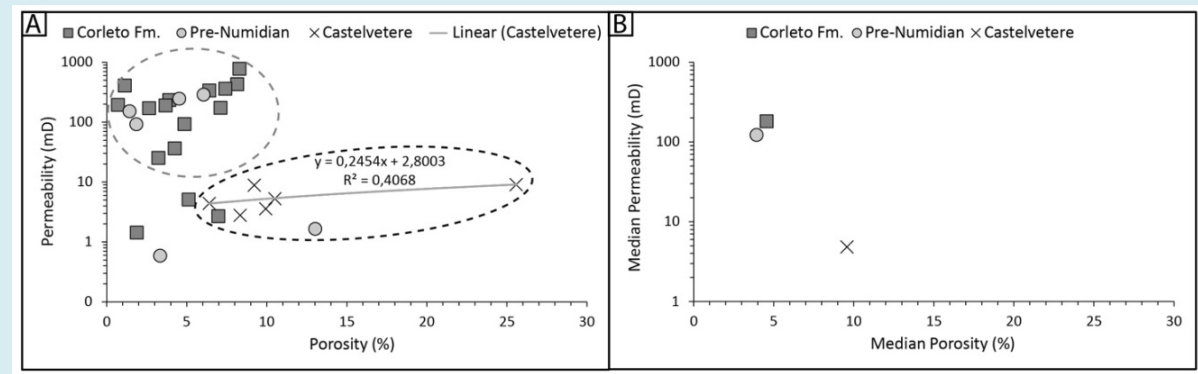

Figure 14: (A) Cross plots of the porosity vs permeability in which all the studied samples are differentiated according the formation of which they are part. The dashed black and grey circles highlight the presence of two clusters, one characterized by good permeability and bad porosity, the other by good porosity and bad permeability. The grey line represents the linear correlation existing in the Castelvetere Fm. (B) Cross plot of the median porosity vs median permeability in which the differentiation of the cluster is clearer. 


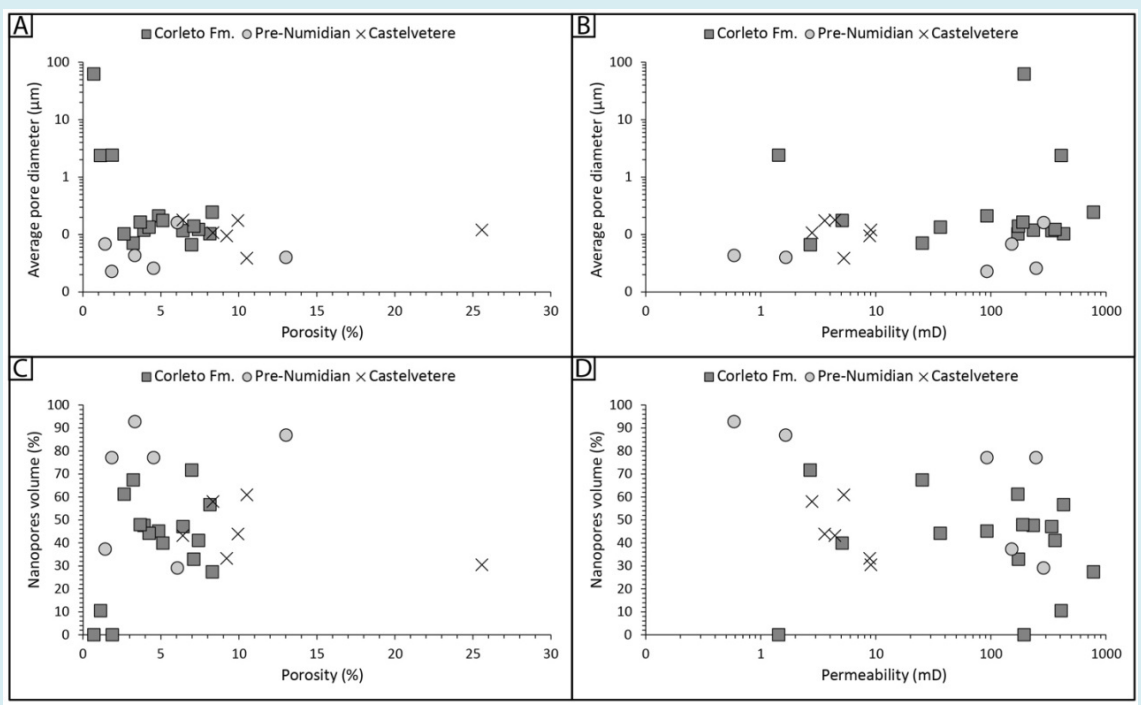

Figure 15: Cross plots in which all the studied samples are reported, highlighting the relationships between the average pore diameter and porosity (A), average pore diameter and permeability (B), nanopores volume and porosity (C), nanopores volume and permeability (D).

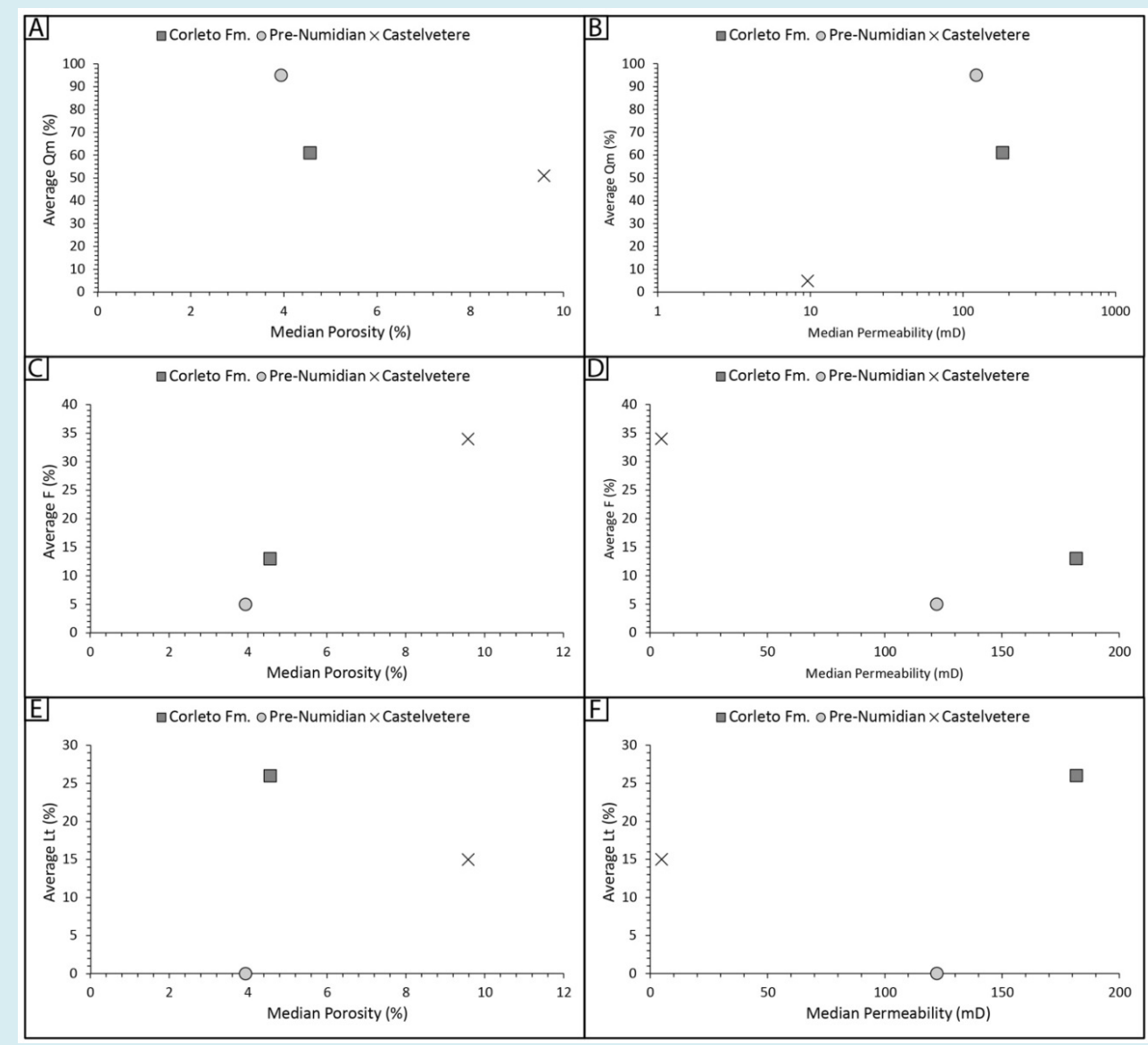

Figure 16: Cross plots in which the median porosity is related to the average abundance of quartz (A), feldspars (C) and lithic fragments (E), and the median permeability is related to the average abundance of quartz (B), feldspars (D), lithic fragments (F). 


\section{Petroleum \& Petrochemical Engineering Journal}

\section{Conclusion}

The Pavoncelli-bis water-supply tunnel represents one of the most important strategic civil engineering works for Southern Apennines. During its construction a good improvement of the geological knowledge was made, highlighting the presence of three main turbiditic siliciclastic formations (Corleto, pre-Numidian/Numidian and Castelvetere formations), crossed by the tunnel trace, that potentially represent good water-reservoirs. These turbiditic sandstone formations are intensely investigated also for their hydrocarbon-reservoirs potential all along the southern Apennines. Consequenlty, this work has been finalized to the detailed petrophysical characterization of these formations through the use of the high-pressure mercury injection porosimetry. Particularly, two main clusters of data have been highlighted, one represented by the Corleto and Pre-Numidian Fms. Characterized by good permeability (respectively $181.70 \mathrm{mD}$ and $122.25 \mathrm{mD}$ in median) and low porosity (respectively $4.56 \%$ and 3.94 $\%$ in median); the other, represented by the Castelvetere Formation with good porosity values (9.58 \% in median) but very low permeability ( $4.84 \mathrm{mD}$ in median). The major differences, that also better differentiate these clusters, are linked with permeability (the porosity differences are less maked). The other parameters of average pore diameter, and nanopores volume, instead do not show any particular trend.

Good correlations exist between porosity and the sandstone composition $(\mathrm{Qm}, \mathrm{F}, \mathrm{Lt})$. In particular, porosity results negatively correlated to the abundance of monocrystalline quartz $(\mathrm{Qm})$, since to an its increase correspond a porosity decrease. On the contrary, porosity is positively correlated with feldspars (F) abundance, since to an its increase correspond also an increase in porosity. The lithic fragments (Lt) values are sparse and do not show any specific trend. These trends can be linked with the different diagenetic processes involving the clusters represented by the Corleto and pre-Numidian Fms. (rich of Qm) and by the Castelvetere Fm. (rich of F). Particularly, where quartz is more abundant, the processes of quartz cementation and overgrowth are more efficient and widespread, resulting in a porosity loss. On the contrary, where feldspars are abundant, the main diagenetic effect is to prompt their dissolution with the consequence of creating new pore spaces and clay minerals. These latter, coat the quartz grains present in the sandstones inhibiting the quartz cementation and overgrowth. Moreover, they show higher pore spaces than the previous feldspars that is however less connected since the pore are mostly isolated and/or blind.

In conclusions, the close relations between detrital compositional signature, diagenitic evolution and petrophysical properties of turbiditic sandstones in foreland settings exert a major quality control on reservoirs for both hydrocarbon and water-supply aims. This example may have general implications on a regional scale and can be applied in analogue fold-thrust belt and foreland setting settings.

\section{Conflicts of Interest}

The authors declare no conflict of interest.

\section{Acknowledgements}

We gratefully acknowledge the critical and constructive comments of anonimous reviewers. This paper was supported and is a contribution of the "Laboratory of Geodynamics, GeoPaleobiology and Earth Surface Processes" (Resp. S. Critelli) of the Department of Biology, Ecology and Earth Sciences at the University of Calabria. This research was supported with grants of the project Relationships between Tectonic Accretion, Volcanism and Clastic Sedimentation within the Circum-Mediterranean Orogenic Belts, 2006-2018; support to S. Critelli).

\section{Funding}

This research was funded by MIUR (Italian Ministry of Education, University and Research), the 2006-2008 MIUR-PRIN Project 2006.04.8397 "The Cenozoic clastic sedimentation within the circum-Mediterranean orogenic belts: implications for palaeogeographic and palaeotectonic evolution", and the University of Calabria MIUR-ex60\% Projects (Palaeogeographic and Palaeotectonic Evolution of the Circum-Mediterranean Orogenic Belts, 2001-2005; and Relationships between Tectonic Accretion, Volcanism and Clastic Sedimentation within the Circum-Mediterranean Orogenic Belts, 2006-2018; support to S. Critelli).

\section{References}

1. Casero P, Roure F, Endignoux, L, Moretti I, Muller C, et al. (1988) Neogene geodynamic evolution of the Southern Apennines. Mem Soc Geol It 41: 109-120.

2. Patacca E, Scandone P (1989) Post Tortonian mountain building in the Apennines. In: Boriani A, Bonafede $\mathrm{M}$, Piccardo GB, Vai GB (Eds.), The lithosphere in Italy: Advances in earth science research. Nat Comm Int Lith Progr, Rome, Italy.

3. Oldow JS, D’Argenio B, Ferranti l, Pappone G, Marsella E, et al. (1993) Large-scale longitudinal extension in the Southern Apennines contractional belt, Italy. Geology 21(12): 1123-1126.

4. Iannace A, Zamparelli V (2002) Upper Triassic platform margin biofacies and the paleogeography of Southern 


\section{Petroleum \& Petrochemical Engineering Journal}

Apennines. Palaeogeogr Palaeoclimat Palaeoecol 179(12): 1-18.

5. Anonymous (1929) The Apulian Acqueduct, Southern Italy. Engineering, pp: 35-36.

6. Cotecchia V, Salvemini A, Ventrella NA (1990) Interpretazione degli abbassamenti territoriali indotti dal terremoto del 23 Novembre 1980 e correlazioni con i danni osservati su talune strutture ingegneristiche dell'area epicentrale irpina. Rivista Italiana di Geotecnica 4: 145-158.

7. Servizio Geologico d'Italia (1970a) Carta Geologica d'Italia alla scala 1:100.000. $\mathrm{F}^{\circ}$ 186, S. Angelo de Lombardi, Roma.

8. Servizio Geologico d'Italia (1970b) Carta Geologica d'Italia alla scala 1:100.000. $\mathrm{F}^{\circ}$ 198, Eboli, Roma.

9. Matano F, Di Nocera S, Critelli S, Criniti S (2020) Geology of the epicentral area of the 1980 earthquake (Irpinia, Italy): new stratigraphical, structural and petrological constrains. Geosciences 10(6): 247.

10. Kaczmarek SE, Fullmer SM, Hasiuk FJ (2015) A universal classification scheme for the microcrystals that host Limestone microporosity. J Sediment Res 85(10): 1197 1212.

11. Olanipekun BJ, Azmy K (2016) Genesis and morphology of intracrystalline nanopores and mineral micro inclusions hosted in burial dolomite crystals: application of Broad Ion Beam-Scanning Electron Microscope (BIBSEM). Mar Petroleum Geol 74: 1-11.

12. Słowakiewicz M, Perri E, Tucker E (2016) Micro- and nanopores in tight Zechstein 2 carbonate facies from the southern permian basin, NW europe. J Petroleum Geol 39(2): 149-168.

13. Perri E, Borrelli M, Spadafora A, Critelli S (2017) The role of microbialitic facies in the micro- and nanopore system of dolomitized carbonate platform (Upper Triassic- Southern Italy). Mar Petrol Geol 88: 1-17.

14. Borrelli M, Campilongo G, Critelli S, Perrotta DI, Perri E (2019) 3D nanopores modeling using TEM-tomography (dolostones - Upper Triassic). Marine and Petroleum Geology 99: 443-452.

15. Westaway RWC, Jackson JA (1980) Surface faulting in the southern Italian Campania-Basilicata earthquake of 23 November 1980. Nature 312: 436-438.

16. Pingue F, De Natale G (1993) Fault mechanism of the 40 seconds subevent of the 1980 Irpinia (Southern Italy) earthquake from levelling data. Geophysical Research Letters 20(10): 911-914.

17. Critelli S (1999) The interplay of lithospheric flexure and thrust accommodation in forming stratigraphic sequences in the southern Apennines foreland basin system, Italy. Lincei Scienze Fisiche e Naturali Rendiconti 10: 2057-326.

18. Critelli S (2018) Provenance of Mesozoic to Cenozoic circum-Mediterranean sandstones in relation to tectonic setting. Earth-Science Reviews 185: 624-648.

19. Critelli S, Le Pera E (1994) Detrital modes and Provenance of Miocene sandstones and Modern sands of the Southern Apennines thrust-top basins (Italy). J Sediment Res 64(4a): 824-835.

20. Critelli S, Le Pera E (1995a) Tectonic evolution of the Southern Apennines thrust-belt (Italy) as reflected in modal compositions of Cenozoic sandstone. The Journal of Geology 103(1): 95-105.

21. Critelli S, Le Pera E (1995b) La Formazione di Castelvetere nell'evoluzione petrostratigrafica dell'avanfossa del Tortoniano-Messiniano dell'Appennino meridionale. Bollettino della Società Geologica Italiana 114: 615-634.

22. Critelli S, Le Pera E (1998) Post-Oligocene sediment dispersal systems and unroofing history of the Calabrian Microplate, Italy. Int Geol Rev 40(7): 609-637.

23. Critelli S, Le Pera E (2003) Provenance relations and modern sand petrofacies in an uplifted thrust-belt, northern Calabria, Italy. In: Valloni R, Basu A (Eds.), Quantitative Provenance Studies in Italy. Servizio Geologico Nazionale, Memorie Descrittive della Carta Geologica d'Italia 61: 25-39.

24. Critelli S, Muto F, Tripodi V, Perri F (2011) Relationships between lithospheric flexure, thrust tectonics and stratigraphic sequences in foreland setting: The Southern Apennines foreland basin system, Italy. In: Schattner U (Ed.), New Frontiers in Tectonic Research at the Midst of Plate Convergence. Intech Open Access Publisher, Janeza Trdine 9, Rijeka, Croatia, pp: 121-170.

25. Critelli S, Muto F, Tripodi V, Perri F (2013) Link between thrust tectonics and sedimentation processes of stratigraphic sequences from the southern Apennines foreland basin system, Italy. Rendiconti Online Società Geologica Italiana 25: 21-42.

26. Critelli S, Muto F, Perri F, Tripodi V (2017) Interpreting provenance relations from sandstone detrital modes, southern Italy foreland region: Stratigraphic record of 


\section{Petroleum \& Petrochemical Engineering Journal}

the Miocene tectonic evolution. Marine and Petroleum Geology 87: 47-59.

27. Ricci Lucchi F (1986) The Oligocene to recent foreland basins of the northern Apennines. In: Allen PA, Homewood P (Eds.), Foreland Basins. Int Ass Sediment 8: 105-139.

28. Boccaletti M, Ciaranfi N, Cosentino D, Deiana G, Gelati R, et al. (1990) Palinspastic restoration and paleogeographic reconstruction of the peri-Tyrrhenian area during the Neogene. Paleogeogr Paleoclim Paleoecol 77(1): 41-42.

29. Critelli S, Le Pera E, Galluzzo F, Milli S, Moscatelli M, et al. (2007) Interpreting siliciclastic-carbonate detrital modes in Foreland Basin Systems: an example from Upper Miocene arenites of the Central Apennines, Italy. In: Arribas J, Critelli S, Johnsson M (Eds.), Sedimentary Provenance and Petrogenesis: Perspectives from Petrography and Geochemistry. Geological Society of America, Special Paper 420: 107-133.

30. Amendola U, Perri F, Critelli S, Monaco P, Cirilli S, et al. (2016) Composition and provenance of the Macigno Formation (Late Oligocene-Early Miocene) in the Trasimeno Lake area (Northern Apennines). Marine and Petroleum Geology 69: 146-167.

31. Stalder NF, Fellin MG, Caracciolo L, Guillong M, Winkler W, etal. (2018) Dispersal pathways in the early Messinian Adriatic foreland and provenance of the Laga Formation (Central Apennines, Italy), Sedimentary Geology 375: 289-308.

32. Malinverno A, Ryan WBF (1986) Extension in the Tyrrhenian Sea and shortening in the Apennines as result of arc migration driven by sinking of the lithosphere. Tectonics 5(2): 227-245.

33. Patacca E, Sartori R, Scandone P (1990) Tyrrhenian basin and Apenninic arcs: kinematic relations since Late Tortonian times. Mem Soc Geol It 45: 425-451.

34. Patacca E, Sartori R, Scandone P (1993) Tyrrhenian basin and Apennines. Kinematic evolution and related dynamic constraints. In: Boschi E (Ed.), Recent Evolution and Seismicity of the Mediterranean Region. Kluwer Academic Publishing, pp: 161-171.

35. Argnani A, Marani M, Savelli C, Galassi B (1995) Migrazione del vulcanismo di arco cenozoico nel contesto geodinamico intraorogenico del Mar Tirreno meridionale: un riesame. In: Polino R, Sacchi R (Eds.), Rapporti Alpi-appennino. Accademia Nazionale delle Scienze, Roma, pp: 377-396.
36. Doglioni C, Harabaglia P, Martinelli G, Mongelli F, Zito G (1996) A geodynamic model of the southern Apelnaoes accretionary prism. Terra nova 8(6): 540-547.

37. Gueguen E, Doglioni C, Fernandez M (1997) Lithospheric boudinage in the western Mediterranean back-arc basin. Terra nova 9(4): 184-187.

38. Gueguen E, Doglioni C, Fernandez M (1998) On the post-25 Ma geodynamic evolution of the western Mediterranean. Tectonophysics 298(1-3): 259-269.

39. Doglioni C (1991) A proposal for the kinematic modelling of W-dipping subduction possible applications to the Tyrrhenian-Apennines system. Terra nova 3(4): 423434.

40. Di Nocera S, Iannace A, Torre M, Basso C, Caiazzo C, et al. (2020) Note Illustrative del Foglio 468. Note Illustrative della Carta Geologica d'Italia alla scala 1:50000. ISPRA Servizio Geologico d'Italia.

41. Pescatore TS, Pinto F (2016) Note Illustrative del Foglio 450. Note Illustrative della Carta Geologica d'Italia alla scala 1:50000, ISPRA - Servizio Geologico d'Italia, S. Angelo dei Lombardi, Italia.

42. Ingersoll RV, Bullard TF, Ford RL, Grimm JP, Pickle JD, Sares SW (1984) The effect of grain size on detrital modes: a test of the Gazzi-Dickinson point-counting method. Journal of Sedimentary Petrology 54(1): 103116.

43. Zuffa GG (1985) Optical analysis of arenites: influence of methodology on compositional results. In: Zuffa GG (Ed.), Provenance of Arenites. NATO ASI Series, Springer, D. Reidel, Dordrecht, pp: 165-189.

44. Zuffa GG (1987) Unravelling hinterland and offshore paleogeography from deepwater arenites. In: Leggett JK, Zuffa GG (Ed.), Deep-Marine Clastic Sedimentology: Concepts and Case Studies. Graham and Trotman, London, pp: 39-61.

45. Dickinson WR (1970) Interpreting detrital modes of graywacke and arkose. J Sediment Petrol 40(2): 695-707.

46. Dickinson WR (1985) Interpreting provenance relations from detrital modes of sandstones. In: Zuffa GG (Ed.), Provenance of Arenites. Nato ASI series, Springer, Dordrecht, The Netherlands, pp: 333-361.

47. Critelli S, Ingersoll RV (1995) Interpretation of neovolcanic versus palaeovolcanic sand grains: an example from Miocene deep-marine sandstone of the Topanga Group (southern California). Sedimentology 42(5): 783-804. 


\section{Petroleum \& Petrochemical Engineering Journal}

48. Zuffa GG (1980) Hybrid arenites: Their composition and classification. J Sediment Petrol 50(1): 21-29.

49. Critelli S, De Rosa R, Sonnino M, Zuffa GG (1990) Significato dei depositi vulcanoclastici della Formazione delle Tufiti di Tusa (Miocene inferiore, Lucania meridionale). Boll Soc Geol It 109: 743-762.

50. Washburn EW (1921) The dynamics of capillary flow. Phys Rev 17: 273.

51. KatzAJ, Thompson AH (1987) Prediction of rock electrical conductivity from mercury injection measurements. J Geophys Res 92(B1): 599-607.

52. Loucks RG, Reed RM, Ruppel SC (2012) Spectrum of pore types and networks in mudrocks. Presented and a descriptive classification for matrix-related mudrocks pores. AAPG Bullettin 96: 1071-1078.

53. Critelli S (1993) Sandstone detrital modes in the Paleogene Liguride Complex, accretionary wedge of the Southern Apennines (Italy). J Sediment Petrol 63(3): 464-476.

54. Perri F, Critelli S, Cavalcante F, Mongelli G, Sonnino M, et al. (2012) Provenance signatures for the Miocene volcaniclastic succession of the Tufiti di Tusa Formation, southern Apennines, Italy. Geological Magazine 149(3): 423-442.

55. Caracciolo L, Arribas J, Ingersoll RV, Critelli S (2015) The diagenetic destruction of porosity in plutoniclastic petrofacies: The Miocene Diligencia and Eocene Maniobra formations, Orocopia Mountains, southern California, USA. In: Scott RA, Smyth HR, Morton AC, Richardson N, (Eds.), Sediment Provenance Studies in Hydrocarbon Exploration and Production. Geological Society, Special Publication, London, 386: 49-62.

56. Fornelli A, Micheletti F, Langone A, Perrone V (2015) First U-Pb detrital zircon ages from Numidian sandstone in southern Apennines: evidences of African provenance. Sediment Geol 320: 19-29.

57. Barbera G, Critelli S, Mazzoleni P (2011) Petrology and geochemistry of Cretaceous Sedimentary Rocks of the Monte Soro Unit (Sicily, Italy): constraints on weathering, diagenesis and provenance. Journal of Geology 119(1): 51-68.

58. Thomas MFH, Bodin S, Redfern J, Irving DHB (2010) Constrained African craton source for the Cenozoic Numidian Flysch: Implications for the palaeogeography of the western Mediterranean basin. Earth Sci Rev 101(1-2): 1-23.
59. Critelli S, Perri F, Arribas J, Herrero MJ (2018) Sandstone detrital modes and diagenetic evolution of Mesozoic continental redbeds from western-central circumMediterranean orogenic belts. In: Ingersoll RV, Lawton TF, Graham S (Eds.), Tectonics, Sedimentary Basins and Provenance: A Celebration of William R. Dickinson's Career. Geological Society of America, Special Paper, 540: 119-132.

60. Wilson MD (1994) Reservoir Quality Assessment and Prediction in Clastic Rocks. Society for Sedimentary Geology (SEPM) Short Course 30: 432.

61. Montgomery C, Fisk JE, Newcombe R, Murphy PN (2005) The differential effects of ecstasy/polydrug use on executive components: shifting, inhibition, updating and access to semantic memory. Psychopharmacology 182(2): 262-276.

62. Javadpour F (2009) Nanopores and apparent permeability of gas flow in mudrocks (shales and siltstone). J Can Petrol Technol 48(8): 16-21.

63. Loucks RG, Reed RM, Ruppel SC, Jarvie DM (2009) Morphology, genesis, and distribution of nanometerscale pores in siliceous mudstones of the Mississippian Barnett Shale. J Sediment Res 79: 848-861.

64. Loucks RG, Lucia FJ, Waite LE (2013) Origin and description of the micropore network within the Lower Cretaceous Stuart City trend tight-gas limestone reservoir in Pawnee field in South Texas. GCAGS J 2: 2941.

65. Nelson PH (2009) Pore throat sizes in sandstones, tight sandstones, and shales. American Association of Petroleum Geologists Bulletin 93(3): 329-340.

66. Chalmers GR, Bustin RM, Power IM (2012) Characterization of gas shale pore systems by porosimetry, pycnometry, surface area, and field emission scanning electron microscopy/transmission electron microscopy image analyses: examples from the Barnett, Woodford, Haynesville, Marcellus, and Doig units. AAPG Bull 96(6): 1099-1119.

67. Lander RH, Walderhaug $O$ (1999) Reservoir quality prediction through simulation of sandstone compaction and quartz cementation. AAPG Bulletin 83: 433-449.

68. Walderhaug O (1996) Kinetic modelling of quartz cementation and porosity loss in deeply buried sandstone reservoirs. AAPG Bulletin 80(5): 731-745.

69. Worden R, Morad S (2000) Quartz cementation in oil field sandstones: A review of the key controversies. 
Quartz cementation in sandstones 29: 1-20.

70. Worden RH, Mayall M, Evans IJ (2000) The effect of ductile-lithic sand grains and quartz cement on porosity and permeability in Oligocene and lower Miocene clastics, South China Sea: prediction of reservoir quality. AAPG Bulletin 84(3): 345-359.

71. McBride EF (1989) Quartz cement in sandstones: a review. Earth Science Reviews 26(1-3): 69-112.

72. Heald MT, Larese RE (1974) Influence of coatings on quartz cementation. Journal of Sedimentary Petrology 44(4): 1269-1274.

73. Giles MR, de Boer RB (1989) Secondary porosity:
Creation of enhanced porosities in the subsurface from the dissolution of carbonate cements as a result of cooling formation waters. Marine and Petroleum Geology 6(3): 261-269.

74. Stoessel RK, Pittman ED (1990) Secondary porosity resisted: the chemistry of feldspar dissolution by carboxylic acids and anions. American Association of Petroleum Geology 74: 1795-1805.

75. Baruch ET, Kennedy MJ, Lohr SC, Dewhurst DN (2015) Feldspar dissolution-enhanced porosityin Paleoproterozoic shale reservoirfacies from the Barney Creek Formation (McArthur Basin, Australia). AAPG Bull 99(9): 1745-1770. 